\title{
Culture, Diffusion, and Economic Development: The Problem of Observational Equivalence*
}

\author{
Ani Harutyunyan ${ }^{\dagger}$ and Ömer Özak ${ }^{\ddagger}$
}

June 20, 2017

\begin{abstract}
This research explores the direct and barrier effects of culture on economic development. It shows both theoretically and empirically that whenever the technological frontier is at the top or bottom of the world distribution of a cultural value, there exists an observational equivalence between absolute cultural distances and cultural distances relative to the frontier, preventing the identification of its direct and barrier effects. Since the technological frontier usually has the "right" cultural values for development, it tends to be in the extremes of the distribution of cultural traits, generating observational equivalence and confounding the analysis. These results highlight the difficulty of disentangling the direct and barrier effects of culture. The empirical analysis finds suggestive evidence for direct effects of individualism and conformity with hierarchy, and barrier effects of hedonism.
\end{abstract}

Keywords: Comparative economic development, cultural differences, barriers to technological diffusion, individualism, power distance, vertical hierarchy, hedonism

JEL Classification: O10, O20, O33, O40, O57, Z10

*We wish to thank an anonymous referee, the editor, Klaus Desmet, Oded Galor, Stelios Michalopoulos, Dan Millimet, Gerard Roland, Assaf Sarid, and David Weil, as well as participants at the 2017 Annual and 2016 European Conferences of the Association for the Study of Religion, Economics, and Culture (ASREC), 15th European Development Network (EUDN) Ph.D. workshop, 3rd PODER/CEPR Summer School and seminar participants at Southern Methodist University and KU Leuven.

${ }^{\dagger}$ LICOS - Centre for Institutions and Economic Performance, KU Leuven. E-mail: ani.harutyunyan@kuleuven.be

${ }_{\ddagger}^{\ddagger}$ Department of Economics, Southern Methodist University. E-mail: ozak@smu.edu. 


\section{Introduction}

Economists have been studying the effects of culture on economic development at least since Weber (1930) proposed his famous "protestant ethic" thesis, which posited that protestantism was conducive to capitalist development due to its emphasis on thrift, hard work, and human capital accumulation (Andersen et al., 2013; Becker and Woessmann, 2009). Additional cultural determinants of comparative development have been suggested in the literature, including differences in levels of trust, cooperation, family ties, individualism, obedience, and attitudes towards work and other individuals (Alesina and Giuliano, 2010, 2014; Giuliano, 2007; Gorodnichenko and Roland, 2016; Guiso et al., 2006, 2009; Knack and Keefer, 1997; Zak and Knack, 2001).

This literature has focused mainly on the direct effects of culture on development, i.e. how having a certain absolute level of a cultural trait affects economic development. Thus, for example, analyzing whether being more or less patient affects development through its impact on human and physical capital accumulation (Dohmen et al., 2015; Galor and Özak, 2016). On the other hand, a more recent strand of the literature has emphasized a potential barrier effect of culture on development, i.e. how relative levels of a cultural trait affect economic development (Basso and Cuberes, 2016; Guiso et al., 2009; Spolaore and Wacziarg, 2009). In particular, cultural differences relative to the technological frontier, like not sharing its religion or language, might act as cultural barriers to technological diffusion and thus lower economic development (Spolaore and Wacziarg, 2012, 2013).

These two types of effects of culture have been identified largely by exploring the differential effects of absolute and relative cultural distances in pairwise country regressions. In particular, if absolute differences in a cultural trait between countries are significantly associated with absolute differences in development then, it is argued, culture has a direct effect. On the other hand, if differences between countries in a cultural trait relative to the technological frontier are significantly associated with absolute differences in development then, it is argued, culture has a barrier effect. The literature has focused on addressing potential threats to identification like reverse causality and omitted variable bias, but it has failed to recognize the problem of observational equivalence between absolute and relative cultural distances, i.e., conditions when these cultural distances are indistinguishable from each other.

This paper identifies the necessary and sufficient conditions for observational equivalence in a cultural trait to hold. In particular, it establishes that observational equivalence holds in a cultural trait if, and only if, the technological frontier is at the top or at the bottom of the global distribution of this cultural trait. Thus, the problem of observational equivalence is created by the location of the technological frontier in the global distribution of cultural values. Importantly, since the technological frontier usually has the "right" cultural values for devel- 
opment, it tends to be in the extremes of the distribution of cultural traits, hence generating observational equivalence and confounding the analysis. While the perfect multicollinearity behind observational equivalence may not hold perfectly, large correlations between absolute and relative cultural distances may still prevent the correct identification of these effects.

This observational equivalence of absolute and relative cultural distances could play an important role in the identification, understanding and implications of the direct and barrier effects of culture. In particular, since these effects might generate completely different policy recommendations it seems important to further understand and disentangle these cultural mechanisms. Interestingly, this observational equivalence and the issues it raises have not been previously identified in the literature. Partly, this omission may be due to the use of genetic distances to proxy for cultural differences. For example, Spolaore and Wacziarg (2009) have shown that differences in contemporary income per capita are associated with relative genetic distances to the United States, thus suggesting a barrier effect of culture. A major drawback of this approach is that it does not identify the cultural values behind these associations and, as will be apparent bellow, it may be confounding the true channel through which culture affects development.

This research advances the understanding of the relation between differences in contemporary income per capita levels and cultural differences between countries and their cultural differences relative to the contemporary technological frontier, i.e. the United States. It establishes that absolute differences in levels of individualism and vertical hierarchy across countries are statistically and economically significantly associated with differences in contemporary income per capita. ${ }^{1}$ On the other hand, linguistic distances and differences in hedonism are the only cultural differences relative to the United States that are statistically and economically significantly associated with differences in contemporary income. Moreover, once these cultural traits are accounted for, genetic distances relative to the US cease to be robustly associated with development. In particular, genetic distances are not significant when differences in individualism are accounted for. Thus, suggesting that the use of genetic distances as proxies for cultural differences may hide the observational equivalence problem and misrepresent the true effects of culture.

The rest of the paper is structured as follows. Section 2 studies the problem of observational equivalence in a general theoretical setting and identifies the necessary and sufficient conditions for its presence. Section 3 explores the problem of observational equivalence empirically. Specifically, it introduces the data and presents the main empirical results. Section 4 concludes.

\footnotetext{
${ }^{1}$ Individualism has also been linked to the timing of the fertility transition (Basso and Cuberes, 2016).
} 


\section{Observational Equivalence in Theory}

This section shows the problem of observational equivalence in the study of the relation between cultural differences and economic development. In particular, it establishes the necessary and sufficient conditions for observational equivalence to hold. ${ }^{2}$ Moreover, it shows that whenever observational equivalence holds, an empirical researcher may draw wrong conclusions about the effect of culture.

Assume income per capita in country $i$ in a balanced growth path depends monotonically on two cultural traits, $\theta_{i} \in[\underline{\theta}, \bar{\theta}]$ and $\sigma_{i} \in[\underline{\sigma}, \bar{\sigma}]$. Specifically, assume that income per capita in country $i$ is given by

$$
y_{i}=h\left(\theta_{i},\left|\sigma_{i}-\sigma_{f}\right|\right),
$$

where $\sigma_{f}$ is the level of $\sigma$ in the technological frontier $f$. Without loss of generality assume that $h$ is strictly increasing in the first component and strictly decreasing in the second component. These assumptions capture the idea that $\theta$ has only a direct effect on development, while $\sigma$ only has a barrier effect on development.

Given a cultural value $\theta$, let $\theta_{i j}$ denote the absolute cultural distance in $\theta$ between countries $i$ and $j$ and $\theta_{i j}^{R}$ denote their relative cultural distance to the frontier in $\theta$. Thus,

$$
\theta_{i j}=\left|\theta_{i}-\theta_{j}\right|, \quad \theta_{i j}^{R}=\left|\theta_{i f}-\theta_{j f}\right| .
$$

Similarly, let $\sigma_{i j}$ denote the absolute cultural distance in $\sigma$ between countries $i$ and $j$ and $\sigma_{i j}^{R}$ denote their relative cultural distance in $\sigma$. Thus, one can rewrite income per capita as $y_{i}=h\left(\theta_{i}, \sigma_{i f}\right)$, which highlights the different effects these two cultural traits have. Let $N=$ $\left\{1, \ldots, N_{c}\right\}$ denote the set of countries.

Definition 2.1. Given a cultural trait $c$, observational equivalence in cultural trait $c$ holds whenever $c_{i j}=c_{i j}^{R}$ for all $i, j \in N .^{3}$

Theorem 2.2. Observational equivalence in cultural trait c holds if, and only if, the technological frontier $f$ is at the top or bottom of the distribution of $c$, i.e., if $c_{f} \leq c_{i}$ for all $i \in N$ or $c_{f} \geq c_{i}$ for all $i \in N$.

Proof. First, let's prove that if $c_{f} \geq c_{i}$ for all $i \in N$, then observational equivalence holds. In

\footnotetext{
${ }^{2}$ The analysis focuses on observational equivalence in pairwise regressions, but it is easy to show using the same type of arguments that the similar necessary and sufficient conditions are required for observational equivalence to hold in country-level regressions.

${ }^{3}$ Given the literature's emphasis on pairwise regressions, the analysis focuses on observational equivalence in this setting. It is not difficult to see that similar problems arise in country-level analyses.
} 
particular, by definition

$$
c_{i j}^{R}=\left|c_{i f}-c_{j f}\right|,
$$

but by assumption

$$
c_{i f}=\left|c_{i}-c_{f}\right|=-\left(c_{i}-c_{f}\right) .
$$

Thus,

$$
c_{i j}^{R}=\left|-\left(c_{i}-c_{f}\right)-\left[-\left(c_{j}-c_{f}\right)\right]\right|=\left|c_{j}-c_{i}\right|=c_{i j} .
$$

The proof for the case when $c_{f} \leq c_{i}$ for all $i \in N$ is similar. Thus, if the technological frontier is at the top or bottom of the distribution of $c$, then observational equivalence in $c$ holds.

To prove the converse, assume observational equivalence holds and for some pair of countries $i, j, c_{i}<c_{f}<c_{j}$. Then,

$$
c_{i j}=\left|c_{i}-c_{j}\right|=-\left(c_{i}-c_{j}\right)=c_{j}-c_{i}, \quad c_{i f}=\left|c_{i}-c_{f}\right|=c_{f}-c_{i}, \quad c_{j f}=\left|c_{j}-c_{f}\right|=c_{j}-c_{f},
$$

so that

$$
c_{i j}^{R}=|| c_{i}-c_{f}|-| c_{j}-c_{f}||=\left|2 c_{f}-\left(c_{i}+c_{j}\right)\right| .
$$

Since observational equivalence holds, it must be that

$$
c_{i j}=c_{j}-c_{i}=\left|2 c_{f}-\left(c_{i}+c_{j}\right)\right| \text {. }
$$

This implies that if $2 c_{f}-\left(c_{i}+c_{j}\right)>0$, then

$$
c_{j}-c_{i}=2 c_{f}-\left(c_{i}+c_{j}\right) \Longleftrightarrow c_{j}=c_{f},
$$

which is a contradiction. Similarly, if $2 c_{f}-\left(c_{i}+c_{j}\right)<0$, then

$$
c_{j}-c_{i}=\left(c_{i}+c_{j}\right)-2 c_{f} \Longleftrightarrow c_{i}=c_{f}
$$

which again is a contradiction. Thus, if observational equivalence holds, either $c_{f} \geq c_{i}$ for all $i \in N$ or $c_{f} \leq c_{i}$ for all $i \in N$.

To see the problems caused by observational equivalence, consider first the case when income per capita is only a function of $\theta$, and thus culture only has direct effects on development. In this case, $y_{i}=h\left(\theta_{i}\right)$, so that the income per capita difference between countries $i$ and $j$ is

$$
y_{i j}=\left|y_{i}-y_{j}\right|=\left|h^{\prime}(\tilde{\theta})\right|\left|\theta_{i}-\theta_{j}\right|+\eta_{i j}=\left|h^{\prime}(\tilde{\theta})\right| \theta_{i j}+\eta_{i j}
$$


for some $\tilde{\theta} \in[\underline{\theta}, \bar{\theta}]$, where $\eta_{i j}$ is the residual in the expansion. This suggests that the structural equation for this case should be of the form

$$
y_{i j}=\alpha+\beta_{\theta} \theta_{i j}+\epsilon_{i j}
$$

But, if observational equivalence in $\theta$ holds, then $\theta_{i j}=\theta_{i j}^{R}$ and a researcher who does not know the true model of the economy may erroneously estimate the following model

$$
y_{i j}=\alpha+\beta_{\theta}^{R} \theta_{i j}^{R}+\epsilon_{i j}
$$

While in this case the estimate of $\beta_{\theta}^{R}$ would be a good estimate of the true structural parameter $\beta_{\theta}$, its interpretation, and any policy recommendation based on it, would be wrong, since they would be based on the assumption of a barrier effect of culture. Moreover, notice that the researcher cannot identify the true effect by estimating

$$
y_{i j}=\alpha+\beta_{\theta} \theta_{i j}+\beta_{\theta}^{R} \theta_{i j}^{R}+\epsilon_{i j}
$$

since $\theta_{i j}$ and $\theta_{i j}^{R}$ are perfectly correlated. Thus, only $\beta_{\theta}+\beta_{\theta}^{R}$ is identified, but the individual values are not. Similarly, if income per capita is only a function of $\sigma$, so that culture only has barrier effects, then $y_{i}=h\left(\sigma_{i f}\right)$ and

$$
\left|y_{i}-y_{j}\right|=\left|h^{\prime}(\tilde{\sigma})\right| \sigma_{i j}^{R}+\eta_{i j}^{R}
$$

for some $\tilde{\sigma} \in[\underline{\sigma}, \bar{\sigma}]$, where $\eta_{i j}^{R}$ is the residual in the expansion. This would suggest a structural equation of the form

$$
y_{i j}=\alpha+\beta_{\sigma}^{R} \sigma_{i j}^{R}+\epsilon_{i j} .
$$

Again, if observational equivalence in $\sigma$ holds, then $\sigma_{i j}^{R}=\sigma_{i j}$ and a researcher who does not know the true model of the economy may erroneously estimate the following model

$$
y_{i j}=\alpha+\beta_{\sigma} \sigma_{i j}+\epsilon_{i j}
$$

As before, the estimate of $\beta_{\sigma}$ would be a good estimate of the true structural parameter $\beta_{\sigma}^{R}$, but its interpretation, and any policy recommendation based on it, would be wrong, since they would be based on the assumption of a direct effect of culture. Moreover, as before, the true effect cannot be identified by estimating

$$
y_{i j}=\alpha+\beta_{\sigma} \sigma_{i j}+\beta_{\sigma}^{R} \sigma_{i j}^{R}+\epsilon_{i j},
$$


since $\sigma_{i j}$ and $\sigma_{i j}^{R}$ are perfectly correlated. Thus, only $\beta_{\sigma}+\beta_{\sigma}^{R}$ is identified, but the individual values are not. Clearly, in the general case, when culture has both direct and barrier effects the structural equation would be of the form

$$
y_{i j}=\alpha+\beta_{\theta} \theta_{i j}+\beta_{\sigma}^{R} \sigma_{i j}^{R}+\epsilon_{i j} .
$$

If observational equivalence in both $\theta$ and $\sigma$ hold, then a researcher may erroneously estimate any of the following equations

$$
y_{i j}=\alpha+\beta_{\theta} \theta_{i j}+\beta_{\sigma} \sigma_{i j}+\epsilon_{i j}, \quad y_{i j}=\alpha+\beta_{\theta}^{R} \theta_{i j}^{R}+\beta_{\sigma} \sigma_{i j}+\epsilon_{i j}, \quad y_{i j}=\alpha+\beta_{\theta}^{R} \theta_{i j}^{R}+\beta_{\sigma}^{R} \sigma_{i j}^{R}+\epsilon_{i j} .
$$

As before, the estimated coefficients would provide correct estimates of the underlying parameters, but their interpretation would be wrong. Moreover, including both the absolute and relative distances cannot help identify the individual parameters.

Note that given a set of $N_{c}$ countries, where a share $\lambda_{c} \in[0,1]$ has a value of the cultural trait $c_{i} \geq c_{f}$, then observational equivalence in $c$ holds for a share

$$
\omega_{c}=\frac{\left[\lambda_{c}^{2}+\left(1-\lambda_{c}\right)^{2}\right] N_{c}-1}{N_{c}-1}
$$

of the sample of all country pairs. Clearly, $\omega_{c} \geq\left(N_{c}-2\right)\left(2 N_{c}-2\right) \approx 0.5$ for large $N_{c}$, which suggests observational equivalence may be affecting the estimation and interpretation of results even in cases where observational equivalence does not hold for the full sample. Moreover, the closer $\lambda_{c}$ is to 0 or 1 , the larger are $\omega_{c}$ and the correlation between $c_{i j}$ and $c_{i j}^{R}$, which increases the possibility of multicollinearity in the analysis.

\section{Observational Equivalence in Praxis}

This section explores empirically the relation between absolute and relative cultural distances and identifies the cases of observational equivalence, when the direct and barrier effect of culture are indistinguishable. Whenever there is no observational equivalence, it attempts to disentangle the direct effect and barrier effects of culture on development.

The research analyzes the effect of culture using six Cultural Dimensions from Hofstede et al. (2010): (i) Power Distance (PDI), which measures the extent to which the less powerful members of society accept and expect power to be unequally distributed; (ii) Individualism vs. Collectivism (IDV), which measures the degree to which individuals are expected to fend for themselves; (iii) Competition vs. Cooperation (CVC), which refers to levels of cooperation and 
competition among members of society; (iv) Uncertainty Avoidance (UAI), which measures the extent to which members of a culture feel threatened by ambiguous and unknown situations; (v) Long-Term Orientation (LTO), which measures the extent to which a culture fosters virtues oriented towards future rewards, in particular perseverance and thrift; (vi) Indulgence vs. Restraint (IVR), which measures the extent to which a culture allows enjoying life and having fun through free gratification of human drives or suppresses them through strict social norms. ${ }^{4}$

For each cultural dimension two distance measures are constructed for each country pair. In particular, given a cultural trait $\theta$, the absolute pairwise distance between countries $i$ and $j, \theta_{i j}$, is given by $\theta_{i j}=\left|\theta_{i}-\theta_{j}\right|$, and the relative pairwise distance to the contemporary technological frontier between countries $i$ and $j, \theta_{i j}^{R}$, is given by $\theta_{i j}^{R}=\left|\theta_{i U S}-\theta_{j U S}\right|$, where it is assumed that the contemporary technological frontier is the US, and $\theta_{i U S}$ is the absolute distance between country $i$ and the US.

Figure 1 depicts the distribution of the six cultural measures. In particular, each panel shows the distribution of a cultural measure, the location of the US in the distribution, the identity of the countries with the highest and lowest levels of the cultural value, as well as the location of the median and the interquartile range. Additionally, for each cultural value it shows the correlation between the absolute and relative cultural distances between countries in the full sample of country pairs. As shown in section 2, if the technological frontier is at the top or bottom of the distribution, the correlation between absolute and relative cultural distances is 1 , as in the case of Individualism. While the case of Individualism is extreme, notice that the US is always outside the interquartile range and the correlation between absolute and relative cultural distances is larger than 0.58 , which should be expected since the technological frontier is bound to have "good" cultural values. Thus, as established in Table 1, observational equivalence is present in over $62 \%$ of the sample of country pairs. Interestingly, even if the subsample where observational equivalence is present is removed, the correlation between absolute and relative cultural distances remains above 0.47 .

The analysis explores the direct and barrier effects of culture on development using a generalization of the empirical specification in Spolaore and Wacziarg (2009), which includes absolute and relative cultural differences, namely

$$
\begin{aligned}
y_{i j}= & \alpha+\beta_{\theta} \theta_{i j}+\beta_{\theta}^{R} \theta_{i j}^{R}+\beta_{G} G D_{i j}+\beta_{G}^{R} G D_{i j}^{R}+\beta_{L} L D_{i j}+\beta_{L}^{R} L D_{i j}^{R}+\beta_{R} R D_{i j}+\beta_{R}^{R} R D_{i j}^{R} \\
& +\sum_{k} \gamma_{k} X_{i j}^{k}+c_{i}+c_{j}+\epsilon_{i j},
\end{aligned}
$$

where the dependent variable, $y_{i j}$, is the absolute value of the pairwise difference in log income per capita in 1995 between country $i$ and $j, \theta_{i j}$ and $\theta_{i j}^{R}$ are their absolute and relative differences

\footnotetext{
${ }^{4}$ The empirical analysis uses all six Hofstede cultural dimensions for the sample of countries for which all measures are available.
} 


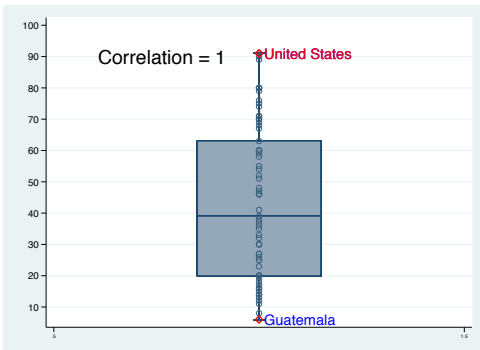

(a) Individualism

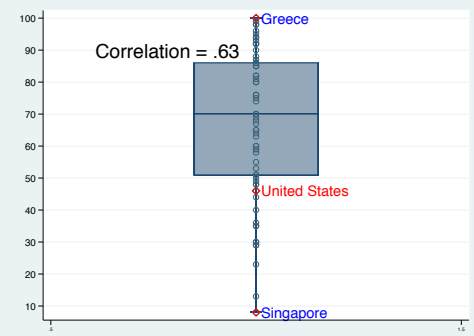

(d) Uncertainty Avoidance

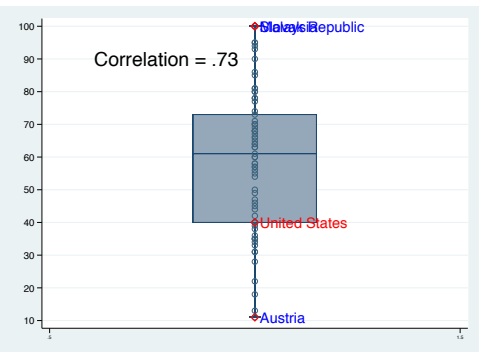

(b) Power Distance

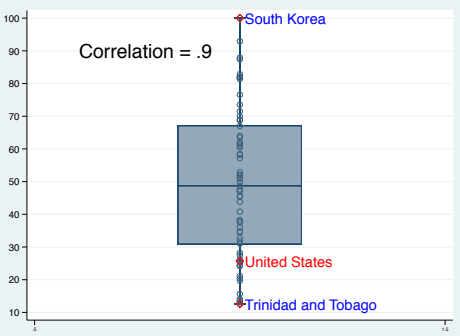

(e) Long-Term Orientation

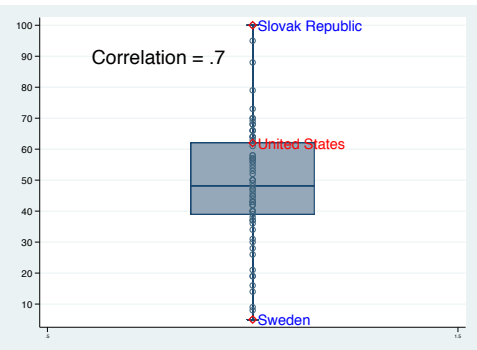

(c) Competition/Cooperation

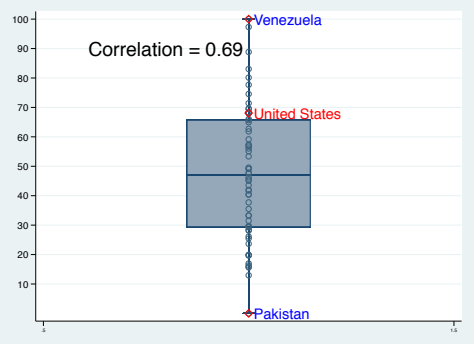

(f) Indulgence/Restraint

Figure 1: Location of U.S. in the Distribution of Hofstede Dimensions

in one of the cultural values defined above, $G D_{i j}$ is their genetic distance, $G D_{i j}^{R}$ is their relative genetic distance to the US, $L D_{i j}$ is their linguistic distance, $L D_{i j}^{R}$ is their relative linguistic distance, $R D_{i j}$ is their religious distance, $R D_{i j}^{R}$ is their relative religious distance, $\left\{X_{i j}^{k}\right\}_{k}$ is a large set of additional pairwise controls, including geographic distances and differences in geographic factors (absolute latitude, landlocked, island, close to coast or river, terrain ruggedness, agricultural and caloric suitability, climatic zones, etc.), common history (ever same country, ever in colonial relationship, have common colonizer), a complete set of continental fixed effects (whether one, both or none of the countries in the pair belong to a specific continent), $c_{i}$ and $c_{j}$ are country fixed effects, and $\epsilon_{i j}$ is an error term. ${ }^{5}$ Given that the construction of differences can potentially generate correlation across observations for each country $i$, the analysis clusters standard errors at two levels, one for each country in the pair (Cameron et al., 2011; Spolaore and Wacziarg, 2009).

Table 2 explores the partial correlation between differences in economic development, relative genetic distances and cultural distances. Column 1 shows that genetic distance relative to frontier is significantly associated with income differences for the subset of countries for which the cultural values are available. Columns 2-7 account for absolute cultural distances, while columns 9-14 account for relative distances to the US for these cultural values. The results

\footnotetext{
${ }^{5}$ Given space constraints, the results shown in the main body of the paper use only this set of controls and cultural measures. Reassuringly, inclusion of a larger set of controls and expansion of the analysis to additional measures of culture based on the World Values Survey does not affect the results (Harutyunyan and Özak, 2016).
} 
Table 1: Observational Equivalence in Subsamples

\begin{tabular}{llllllll}
\hline & \multicolumn{5}{c}{ Subsample of Country Pairs for which Cultural Value in US is } \\
\cline { 2 - 3 } & \multicolumn{2}{c}{ Higher/Lower than Values in Both } & & \multicolumn{3}{c}{ Between Values in Both } \\
\cline { 2 - 3 } & Correlation & Observations & Share & & Correlation & Observations & Share \\
\hline Individualism & $1.00^{* * *}$ & 1,830 & 1.00 & & NA & 0 & 0.00 \\
Power Distance & $1.00^{* * *}$ & 1,206 & 0.66 & & $0.58^{* * *}$ & 624 & 0.34 \\
Competition/Cooperation & $1.00^{* * *}$ & 1,140 & 0.62 & & $0.58^{* * *}$ & 690 & 0.38 \\
Uncertainly Avoidance & $1.00^{* * *}$ & 1,280 & 0.70 & & $0.50^{* * *}$ & 550 & 0.30 \\
Long-Term Orientation & $1.00^{* * *}$ & 1,280 & 0.70 & & $0.88^{* * *}$ & 550 & 0.30 \\
Indulgence/Restraint & $1.00^{* * *}$ & 1,242 & 0.68 & & $0.47^{* * *}$ & 588 & 0.32 \\
\hline
\end{tabular}

Notes: This table explores the strength of observational equivalence for various cultural traits. It shows the correlation between absolute and relative cultural distances for the subsamples of country pairs for which the cultural value in the US is either higher or lower than the values in both countries in the pair or the value in the US is between the values of the country pair. Observational equivalence holds in the first subsample (by definition), so its share provides a measure of the problem. *** denotes statistical significance at the $1 \%$ level, ${ }^{* *}$ at the $5 \%$ level, and ${ }^{*}$ at the $10 \%$ level, all for two-sided hypothesis tests.

suggest that Individualism and Power Distance have direct effects on economic development, while Individualism and Indulgence vs Restraint have barrier effects on development. Columns 8 and 15 respectively account for all absolute and relative cultural distances jointly with similar results.

The results of columns 2 and 9 establish that once one accounts for differences in Individualism, the genetic distance relative to the US ceases to be associated with differences in economic development. This suggests that genetic distances relative to the US might be capturing the effect of differences in Individualism. This view is supported by Harutyunyan and Özak (2016), which established the strong association between genetic distances and differences in Individualism. Furthermore, they also show that relative distances in Individualism are the only relative cultural trait that is economically and statistically significantly correlated with relative genetic distances.

While these results suggest that relative genetic distances might be capturing the barrier effect of Individualism, this interpretation is subject to the problem of observational equivalence. In particular, given that the US has the highest value of Individualism (see Figure 1(a)), the absolute and relative distances are observationally equivalent. Indeed, the estimated effect of absolute and relative differences in Individualism is identical in columns 2 and 9. So, although column 9 would suggest a barrier effect of individualism, this might just be capturing its direct effect that has been obscured by observational equivalence. Moreover, in light of this observational equivalence and the findings of Harutyunyan and Özak (2016), it is possible that relative genetic distances do not capture the barrier effect, but instead the direct effects of culture.

Although these results suggest one potential mechanism being captured by relative genetic distances, it does not help in the identification of the direct vs barrier effects of these various 


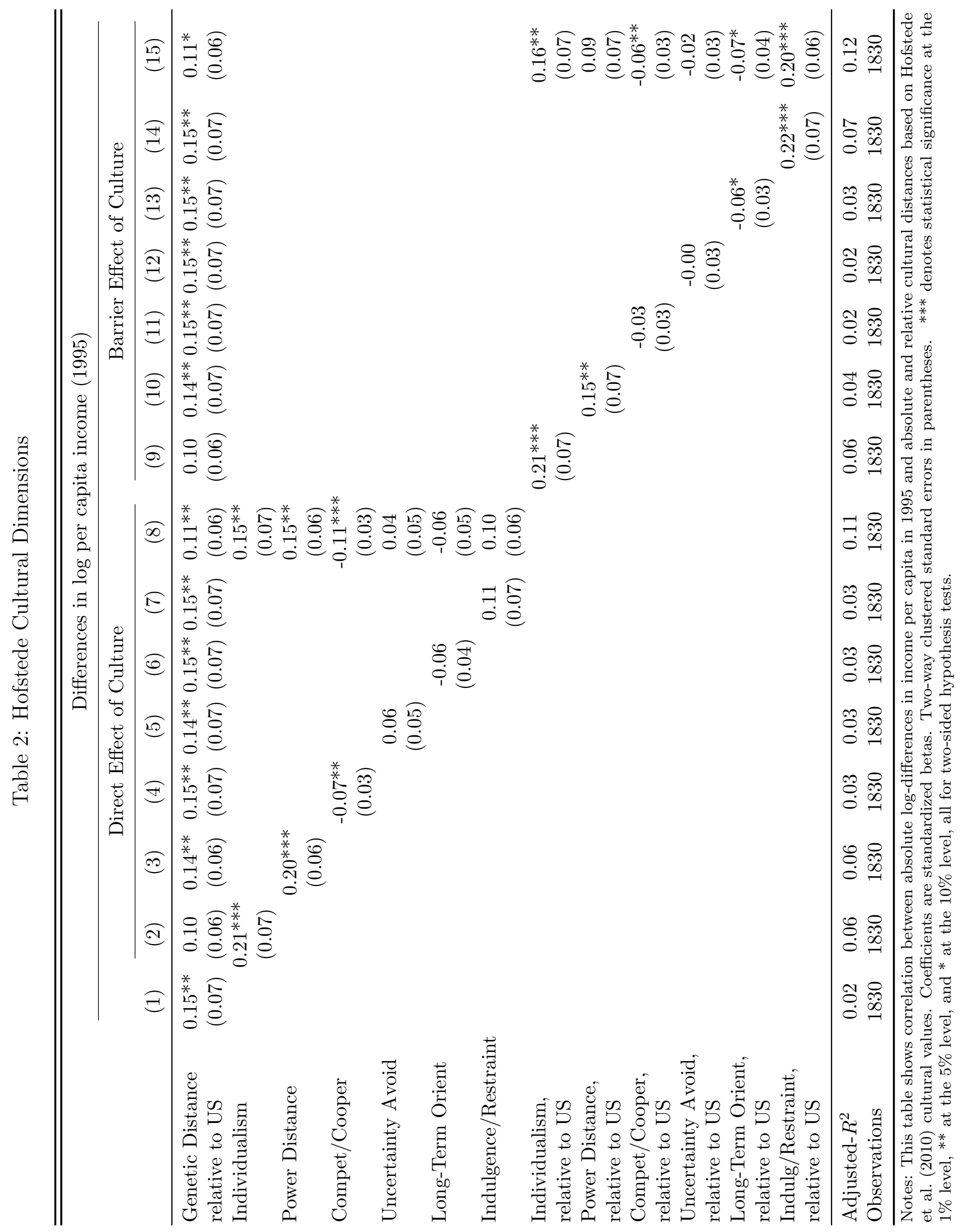


cultural values. In order to analyze this further, Table 3 accounts jointly for both absolute and relative cultural distances. Given the potential bias due to omitted variables, it additionally accounts for geographical differences, pairwise continental fixed effects, other measures of common ancestry, as well as relative linguistic and religious distances. Column 2 shows that differences in Individualism remain strongly associated with differences in economic development. However, since the absolute and relative distances in Individualism are perfectly correlated, the empirical specification does not allow to disentangle the direct and barrier effect of individualism. Indeed, the coefficient on the relative distance in Individualism is 0. Columns 3 and 7 show that the absolute distance in Power Distance and the relative distance in Indulgence vs Restraint are positive economically statistically significantly associated with differences in economic development. These results suggest that Power Distance has a direct effect on economic development, while Indulgence vs Restraint has a barrier effect on development. Finally, Column 8 establishes that similar results hold if the analysis accounts jointly for all cultural differences.

These results suggest that (i) genetic distances relative to the US might be capturing the (direct or barrier) effects of Individualism, (ii) Individualism may have either direct or barrier effects, (iii) Power Distance has significant direct effects, and (iv) Indulgence vs Restraint has significant barrier effects on economic development. While these results suggest the presence of various direct effects, the existence of observational equivalence between absolute and relative distances calls for caution in the interpretation. In particular, although observational equivalence holds only in the case of Individualism, the correlation between absolute and relative distances is high for both Power Distance and Indulgence vs Restraint, increasing the potential for a misidentification of the effects of culture. One potential strategy to address the problem raised by observational equivalence is to analyze the effect of culture only in the subsample where observational equivalence is not present, i.e., by excluding all country pairs for which the cultural value in the US is higher or lower than in both countries in the pair. While this strategy may address the problem of observational equivalence, it may generate other biases due to (non-random) sampling, the exclusion of information, and the reduction in the sample size. Moreover, as Table 1 shows, while this strategy implies the loss of about 2/3 of the sample, it does not eliminate the correlation between absolute and relative cultural distances. In non-reported results, following this strategy the analysis finds further suggestive evidence in favor of a barrier effect of Indulgence vs. Restraint, but finds no significant direct nor barrier effects for any of the other cultural values, suggesting that there may exist significant biases in this subsample. 
Table 3: Hofstede Cultural Dimensions and Income (All Controls)

\begin{tabular}{|c|c|c|c|c|c|c|c|c|}
\hline & \multicolumn{8}{|c|}{ Differences in log per capita income (1995) } \\
\hline & (1) & $(2)$ & (3) & $(4)$ & (5) & (6) & (7) & (8) \\
\hline Genetic Distance & 0.17 & 0.18 & $0.21^{* *}$ & 0.17 & 0.17 & 0.17 & 0.16 & $0.20^{*}$ \\
\hline Relative to US & $(0.16)$ & $(0.12)$ & $(0.11)$ & $(0.15)$ & $(0.14)$ & $(0.15)$ & $(0.16)$ & $(0.12)$ \\
\hline Individualism & & $\begin{array}{c}0.28^{* * *} \\
(0.08)\end{array}$ & & & & & & $\begin{array}{r}0.19^{* *} \\
(0.08)\end{array}$ \\
\hline Power Distance & & & $\begin{array}{c}0.42^{* * *} \\
(0.09)\end{array}$ & & & & & $\begin{array}{c}0.25^{* * *} \\
(0.09)\end{array}$ \\
\hline Competition/Cooperation & & & & $\begin{array}{c}0.03 \\
(0.05)\end{array}$ & & & & $\begin{array}{c}0.01 \\
(0.05)\end{array}$ \\
\hline Uncertainty Avoidance & & & & & $\begin{array}{c}0.09 \\
(0.07)\end{array}$ & & & $\begin{array}{c}0.07 \\
(0.06)\end{array}$ \\
\hline Long-Term Orientation & & & & & & $\begin{array}{l}-0.08 \\
(0.11)\end{array}$ & & $\begin{array}{l}-0.06 \\
(0.10)\end{array}$ \\
\hline Indulgence/Restraint & & & & & & & $\begin{array}{l}-0.10 \\
(0.07)\end{array}$ & $\begin{array}{l}-0.03 \\
(0.07)\end{array}$ \\
\hline $\begin{array}{l}\text { Individualism, } \\
\text { Relative to US }\end{array}$ & & $\begin{array}{c}0.00 \\
(0.00)\end{array}$ & & & & & & $\begin{array}{c}0.00 \\
(0.00)\end{array}$ \\
\hline $\begin{array}{l}\text { Power Distance, } \\
\text { Relative to US }\end{array}$ & & & $\begin{array}{l}-0.13 \\
(0.09)\end{array}$ & & & & & $\begin{array}{l}-0.07 \\
(0.08)\end{array}$ \\
\hline $\begin{array}{l}\text { Competition/Cooperation, } \\
\text { Relative to US }\end{array}$ & & & & $\begin{array}{l}-0.03 \\
(0.04)\end{array}$ & & & & $\begin{array}{c}0.00 \\
(0.04)\end{array}$ \\
\hline $\begin{array}{l}\text { Uncertainty Avoidance, } \\
\text { Relative to US }\end{array}$ & & & & & $\begin{array}{l}-0.04 \\
(0.05)\end{array}$ & & & $\begin{array}{l}-0.09^{*} \\
(0.05)\end{array}$ \\
\hline $\begin{array}{l}\text { Long-Term Orientation, } \\
\text { Relative to US }\end{array}$ & & & & & & $\begin{array}{c}0.04 \\
(0.09)\end{array}$ & & $\begin{array}{c}0.01 \\
(0.10)\end{array}$ \\
\hline $\begin{array}{l}\text { Indulgence/Restraint, } \\
\text { Relative to US }\end{array}$ & & & & & & & $\begin{array}{c}0.32^{* * *} \\
(0.10)\end{array}$ & $\begin{array}{r}0.20^{* *} \\
(0.09) \\
\end{array}$ \\
\hline Genetic Distance & $\begin{array}{l}-0.14 \\
(0.15)\end{array}$ & $\begin{array}{l}-0.23 \\
(0.16)\end{array}$ & $\begin{array}{c}-0.24^{*} \\
(0.14)\end{array}$ & $\begin{array}{l}-0.14 \\
(0.15)\end{array}$ & $\begin{array}{l}-0.16 \\
(0.15)\end{array}$ & $\begin{array}{l}-0.15 \\
(0.15)\end{array}$ & $\begin{array}{l}-0.15 \\
(0.16)\end{array}$ & $\begin{aligned}-0.28^{*} \\
(0.15)\end{aligned}$ \\
\hline Linguistic Distance & $\begin{array}{l}0.14^{*} \\
(0.08)\end{array}$ & $\begin{array}{c}0.07 \\
(0.07)\end{array}$ & $\begin{array}{c}0.05 \\
(0.07)\end{array}$ & $\begin{array}{l}0.14^{*} \\
(0.08)\end{array}$ & $\begin{array}{c}0.13 \\
(0.08)\end{array}$ & $\begin{array}{l}0.15^{*} \\
(0.08)\end{array}$ & $\begin{array}{l}0.15^{*} \\
(0.08)\end{array}$ & $\begin{array}{c}0.06 \\
(0.07)\end{array}$ \\
\hline Religious Distance & $\begin{array}{l}-0.05 \\
(0.13)\end{array}$ & $\begin{array}{l}-0.01 \\
(0.13)\end{array}$ & $\begin{array}{l}-0.07 \\
(0.12)\end{array}$ & $\begin{array}{l}-0.05 \\
(0.13)\end{array}$ & $\begin{array}{l}-0.06 \\
(0.13)\end{array}$ & $\begin{array}{l}-0.05 \\
(0.13)\end{array}$ & $\begin{array}{l}-0.04 \\
(0.13)\end{array}$ & $\begin{array}{l}-0.01 \\
(0.12)\end{array}$ \\
\hline Linguistic Distance & $0.16^{* *}$ & 0.08 & 0.10 & $0.17^{* *}$ & $0.17^{* *}$ & $0.17^{* *}$ & 0.08 & 0.00 \\
\hline Relative to the US & $(0.07)$ & $(0.07)$ & $(0.07)$ & $(0.07)$ & $(0.07)$ & $(0.07)$ & $(0.08)$ & $(0.08)$ \\
\hline Religious Distance & 0.15 & 0.10 & 0.13 & 0.15 & 0.16 & 0.15 & 0.11 & 0.07 \\
\hline Relative to the US & $(0.11)$ & $(0.10)$ & $(0.10)$ & $(0.11)$ & $(0.11)$ & $(0.11)$ & $(0.10)$ & $(0.10)$ \\
\hline Country FE & Yes & Yes & Yes & Yes & Yes & Yes & Yes & Yes \\
\hline Geo Controls & Yes & Yes & Yes & Yes & Yes & Yes & Yes & Yes \\
\hline Historical Controls & Yes & Yes & Yes & Yes & Yes & Yes & Yes & Yes \\
\hline Adjusted- $R^{2}$ & 0.50 & 0.54 & 0.56 & 0.50 & 0.50 & 0.50 & 0.54 & 0.60 \\
\hline Observations & 1596 & 1596 & 1596 & 1596 & 1596 & 1596 & 1596 & 1596 \\
\hline
\end{tabular}

Notes: This table explores the direct and barrier effects of Hofstede's cultural values by running a horse race between absolute and relative cultural distances, including linguistic and religious distances. Coefficients are standardized betas of an Ordinary Least Squares (OLS) regression after accounting for country fixed effects, geographical differences, pairwise continental fixed effects. Two-way clustered standard errors in parentheses. *** denotes statistical significance at the $1 \%$ level, ** at the $5 \%$ level, and $*$ at the $10 \%$ level, all for two-sided hypothesis tests. 


\section{Conclusion}

This research explores the direct and barrier effects of culture on economic development. It shows both theoretically and empirically that whenever the technological frontier is at the top or bottom of the world distribution of a cultural value, there exists an observational equivalence between absolute and relative distances, preventing the identification of direct and barrier effects of this cultural value. More specifically, the analysis establishes that observational equivalence holds in a cultural trait if, and only if, the technological frontier is at the top or at the bottom of the global distribution of this cultural trait. So, given that the technological frontier usually has the "right" cultural values for development, it will tend to be in the extremes of the distribution of cultural traits and generate observational equivalence. Thus, these results highlight the difficulty of disentangling the direct and barrier effects of culture.

The analysis suggests that Individualism and Power Distance have direct effects on development, while Indulgence vs. Restraint has barrier effects. Still, the problem of observational equivalence suggests these effects may be misidentified. In particular, given that the United States is the most individualistic country in the sample, differences in individualism and differences in individualism relative to the US are perfectly correlated. Thus, it is not possible to disentangle the direct and barrier effects in this case as they are observationally equivalent. Moreover, while the case of Individualism is extreme, the correlation between absolute and relative cultural distances is generally high. Also, even when observational equivalence does not hold empirically for the full sample, it does hold for a large subsample of the data.

Since the barrier effect has been studied using relative genetic distances as a proxy for relative cultural distances, the observational equivalence of absolute and relative cultural distances has not been previously identified in the literature. Specifically, since absolute and relative genetic distances are strongly associated with absolute and relative cultural differences (Harutyunyan and Özak, 2016), the observational equivalence of these cultural channels has remained obscured. Importantly, this observational equivalence plays an essential role in the identification and understanding of the direct and barrier effects of culture. Moreover, since these effects may generate completely different policy recommendations it seems important to further understand and disentangle the cultural mechanisms behind each. 


\section{References}

Alesina, A. and Giuliano, P. (2010). The power of the family, Journal of Economic growth 15(2): 93-125.

Alesina, A. and Giuliano, P. (2014). Family ties, Handbook of Economic Growth, Vol. 2, Elsevier, pp. 177-215.

Andersen, T. B., Bentzen, J., Dalgaard, C.-J. and Sharp, P. (2013). Pre-reformation roots of the protestant ethic, Technical report, Competitive Advantage in the Global Economy (CAGE).

Basso, A. and Cuberes, D. (2016). Deep-rooted determinants of the fertility transition across countries., Macroeconomic Dynamics .

Becker, S. O. and Woessmann, L. (2009). Was weber wrong? a human capital theory of protestant economic history, The Quarterly Journal of Economics 124(2): 531-596.

Cameron, A. C., Gelbach, J. B. and Miller, D. L. (2011). Robust inference with multiway clustering, Journal of Business \&6 Economic Statistics 29(2).

Dohmen, T., Enke, B., Falk, A., Huffman, D. and Sunde, U. (2015). Patience and the wealth of nations.

Galor, O. and Özak, Ö. (2016). The agricultural origins of time preference, American Economic Review 106(10).

Giuliano, P. (2007). Living arrangements in western europe: Does cultural origin matter?, Journal of the European Economic Association 5(5): 927-952.

Gorodnichenko, Y. and Roland, G. (2016). Culture, institutions and the wealth of nations, Review of Economics and Statistics .

Guiso, L., Sapienza, P. and Zingales, L. (2006). Does culture affect economic outcomes?, Journal of Economic Perspectives 20(2): 23-48.

Guiso, L., Sapienza, P. and Zingales, L. (2009). Cultural biases in economic exchange?, The Quarterly Journal of Economics 124(3): 1095-1131.

Harutyunyan, A. and Özak, Ö. (2016). Culture, diffusion, and economic development, SMU Working Paper.

Hofstede, G. H., Hofstede, G. J. and Minkov, M. (2010). Cultures and organizations: software of the mind : intercultural cooperation and its importance for survival, 3rd ed edn, McGraw-Hill, New York.

Knack, S. and Keefer, P. (1997). Does social capital have an economic payoff? a cross-country investigation, The Quarterly journal of economics pp. 1251-1288.

Spolaore, E. and Wacziarg, R. (2009). The diffusion of development, The Quarterly Journal of Economics 124(2): 469-529. 
Spolaore, E. and Wacziarg, R. (2012). Long-term barriers to the international diffusion of innovations, NBER International Seminar on Macroeconomics, Vol. 8, JSTOR, pp. 11-46.

Spolaore, E. and Wacziarg, R. (2013). How deep are the roots of economic development?, Journal of Economic Literature 51(2): 325-369.

Weber, M. (1930). The Protestant ethic and the spirit of capitalism, Scribner, New York.

Zak, P. J. and Knack, S. (2001). Trust and growth, The economic journal 111(470): 295-321. 


\section{Appendix (Not for publication)}

\section{A Cultural Measures (Hofstede and WVS)}

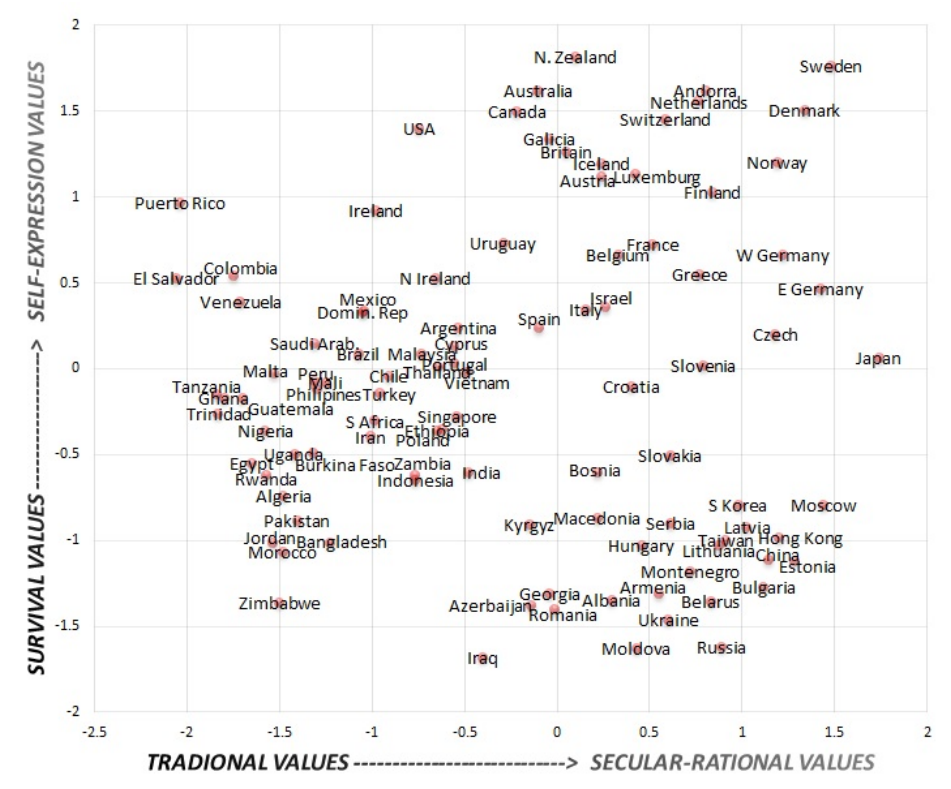

Figure A.1: Cultural map based on the two dimensions of the WVS.

Table A.1: Correlation of the Hofstede Cultural Pairwise Differences

\begin{tabular}{lcccccc}
\hline \hline & \multicolumn{5}{c}{ Correlation Coefficient } \\
\cline { 2 - 6 } & PDI & IDV & CVC & UAI & LTO & IVR \\
\hline Power Distance & 1.00 & & & & \\
Individualism & $0.36^{* * *}$ & 1.00 & & & \\
Compet/Cooper & $0.18^{* * *}$ & $0.04^{*}$ & 1.00 & & & \\
Uncertainty Avoid & $0.14^{* * *}$ & $0.05^{* *}$ & -0.00 & 1.00 & & \\
Long-Term Orientation & $-0.07^{* * *}$ & 0.01 & 0.01 & $-0.06^{* * *}$ & 1.00 & \\
Indulgence/Restraint & $0.11^{* * *}$ & $0.10^{* * *}$ & 0.03 & $-0.05^{* *}$ & $0.19^{* * *}$ & 1.00 \\
\hline
\end{tabular}

Notes: This table shows the correlation coefficients between the pairwise differences of Hofstede Cultural Dimesnions *** denotes statistical significance at the $1 \%$ level, ${ }^{* *}$ at the $5 \%$ level, and * at the $10 \%$ level, all for two-sided hypothesis tests. 
Table A.2: Correlation of the WVS Cultural Pairwise Differences

\begin{tabular}{|c|c|c|c|c|c|c|c|c|c|c|c|c|c|}
\hline & \multicolumn{13}{|c|}{ Correlation Coefficient } \\
\hline & TRV & SSV & Trust & OBD & HW & $\mathrm{FT}$ & WL & $\mathrm{CHT}$ & SCK & EQY & MTO & TOL & PET \\
\hline Traditional/Rational & 1.00 & & & & & & & & & & & & \\
\hline Survival/Self Expression & $0.13^{* * *}$ & 1.00 & & & & & & & & & & & \\
\hline Trust & $0.23^{* * *}$ & $0.44^{* * *}$ & 1.00 & & & & & & & & & & \\
\hline Obedience & $0.42^{* * *}$ & 0.03 & $0.13^{* * *}$ & 1.00 & & & & & & & & & \\
\hline Hard Work & $0.19^{* * *}$ & $0.58^{* * *}$ & $0.28^{* * *}$ & $0.14^{* * *}$ & 1.00 & & & & & & & & \\
\hline Family Ties & $0.54^{* * *}$ & $0.21^{* * *}$ & $0.41^{* * *}$ & $0.41^{* * *}$ & $0.25^{* * *}$ & 1.00 & & & & & & & \\
\hline Work/Luck & $0.06^{*}$ & $-0.12^{* * *}$ & $-0.13^{* * *}$ & 0.04 & $0.20 * * *$ & -0.01 & 1.00 & & & & & & \\
\hline Cheating & 0.05 & $-0.06^{*}$ & -0.05 & -0.05 & -0.05 & 0.01 & $0.07^{* *}$ & 1.00 & & & & & \\
\hline Social Capital & 0.04 & $-0.07^{* *}$ & $-0.07^{* *}$ & $-0.06^{*}$ & $-0.08^{* *}$ & 0.01 & $0.13^{* * *}$ & $0.90^{* * *}$ & 1.00 & & & & \\
\hline Equality & $0.21^{* * *}$ & -0.02 & -0.05 & $0.08^{* *}$ & $0.14^{* * *}$ & $0.12^{* * *}$ & $0.09^{* * *}$ & 0.04 & 0.01 & 1.00 & & & \\
\hline Market Orientation & -0.03 & $0.30^{* * *}$ & 0.05 & -0.05 & $0.18^{* * *}$ & $-0.08^{* *}$ & $0.15^{* * *}$ & 0.01 & 0.01 & -0.02 & 1.00 & & \\
\hline Tolerance & $0.14^{* * *}$ & $0.52^{* * *}$ & $0.24^{* * *}$ & 0.05 & $0.44^{* * *}$ & $0.15^{* * *}$ & $0.13^{* * *}$ & -0.02 & -0.03 & $0.06^{*}$ & $0.16^{* * *}$ & 1.00 & \\
\hline Prot. Ethic & $0.26^{* * *}$ & $-0.07^{* *}$ & 0.02 & $0.16^{* * *}$ & -0.01 & $0.08^{* * *}$ & $0.08^{* *}$ & -0.03 & -0.04 & $0.10^{* * *}$ & -0.02 & $0.11^{* * *}$ & 1.00 \\
\hline
\end{tabular}

Table A.3: Correlation of the Hofstede Cultural Differences Relative to US

\begin{tabular}{lcccccc}
\hline \hline & \multicolumn{5}{c}{ Correlation Coefficients } \\
\cline { 2 - 7 } & PDI & IDV & CVC & UAI & LTO & IVR \\
\hline Power Distance, Relative to US & 1.00 & & & & & \\
Individualism, Relative to US & $0.23^{* * *}$ & 1.00 & & & & \\
Competition/Cooperation, Relative to US & $0.05^{* *}$ & $0.07^{* * *}$ & 1.00 & & & \\
Uncertainty Avoidance, Relative to US & $0.11^{* * *}$ & $0.05^{* *}$ & 0.03 & 1.00 & & \\
Long-Term Orientation, Relative to US & 0.01 & -0.01 & -0.01 & -0.01 & 1.00 & \\
Indulgence/Restraint, Relative to US & $0.12^{* * *}$ & $0.12^{* * *}$ & $0.05^{* *}$ & -0.02 & $0.06^{* * *}$ & 1.00 \\
\hline
\end{tabular}

Notes: This table shows the correlation coefficients between the relative to US differences of Hofstede Cultural Dimesnions $* * *$ denotes statistical significance at the $1 \%$ level, ${ }^{* *}$ at the $5 \%$ level, and ${ }^{*}$ at the $10 \%$ level, all for two-sided hypothesis tests.

Table A.4: Correlation of the WVS Cultural Differences Relative to US

\begin{tabular}{|c|c|c|c|c|c|c|c|c|c|c|c|c|c|}
\hline & \multicolumn{13}{|c|}{ Correlation Coefficient } \\
\hline & TRV & SSV & Trust & OBD & HW & FT & WL & CHT & SCK & EQY & MTO & TOL & PET \\
\hline Traditional/Rational, Relative to US & 1.00 & & & & & & & & & & & & \\
\hline Survival/Self Expression, Relative to US & $0.06^{*}$ & 1.00 & & & & & & & & & & & \\
\hline Trust, Relative to US & $0.13^{* * *}$ & -0.00 & 1.00 & & & & & & & & & & \\
\hline Obedience, Relative to US & -0.04 & $0.12^{* * *}$ & $0.07^{* *}$ & 1.00 & & & & & & & & & \\
\hline Hard Work, Relative to US & 0.04 & $0.40^{* * *}$ & 0.03 & $0.17^{* * *}$ & 1.00 & & & & & & & & \\
\hline Family Ties, Relative to US & $0.45^{* * *}$ & $0.17^{* * *}$ & $0.21^{* * *}$ & $0.09^{* *}$ & $0.07^{* *}$ & 1.00 & & & & & & & \\
\hline Work/Luck, Relative to US & -0.04 & $-0.08^{* *}$ & -0.03 & $-0.08^{* *}$ & 0.01 & 0.02 & 1.00 & & & & & & \\
\hline Cheating, Relative to US & $-0.12^{* * *}$ & $0.12^{* * *}$ & -0.01 & -0.04 & -0.05 & $-0.09 * * *$ & -0.02 & 1.00 & & & & & \\
\hline Social Capital, Relative to US & $-0.12^{* * *}$ & $0.09^{* * *}$ & -0.04 & $-0.07^{* *}$ & $-0.08^{* *}$ & $-0.11^{* * *}$ & $0.07^{* *}$ & $0.84^{* * *}$ & 1.00 & & & & \\
\hline Equality, Relative to US & $-0.08 * *$ & -0.00 & $-0.05^{*}$ & $0.10^{* * *}$ & $0.14^{* * *}$ & $-0.06^{*}$ & -0.03 & -0.02 & -0.04 & 1.00 & & & \\
\hline Market Orientation, Relative to US & 0.00 & $0.14^{* * *}$ & $-0.09 * * *$ & -0.01 & $0.08^{* *}$ & -0.05 & $0.07 * *$ & $0.09^{* * *}$ & $0.08^{* *}$ & -0.00 & 1.00 & & \\
\hline Tolerance, Relative to US & -0.03 & $0.15^{* * *}$ & -0.03 & 0.00 & $0.22^{* * *}$ & 0.03 & 0.00 & -0.01 & -0.04 & $0.09^{* * *}$ & 0.03 & 1.00 & \\
\hline Prot. Ethic, Relative to US & $0.09^{* * *}$ & -0.04 & 0.05 & $0.10^{* * *}$ & $0.06^{*}$ & 0.02 & $-0.06^{*}$ & 0.01 & 0.01 & -0.01 & 0.02 & $0.15^{* * *}$ & 1.00 \\
\hline
\end{tabular}




\section{B Cultural and Genetic Distances}

Table B.1: Regressions when one of the countries is the United States (Hofstede)

\begin{tabular}{|c|c|c|c|c|c|c|}
\hline & \multicolumn{6}{|c|}{ Hofstede Cultural Dimensions (OLS) } \\
\hline & $\begin{array}{c}\text { Power } \\
\text { Distance }\end{array}$ & Individualism & $\begin{array}{r}\text { Competition } \\
\text { Cooperation } \\
\end{array}$ & $\begin{array}{l}\text { Uncertainty } \\
\text { Avoidance }\end{array}$ & $\begin{array}{l}\text { Long-Term } \\
\text { Orientation } \\
\end{array}$ & $\begin{array}{c}\text { Indulgence } \\
\text { Restraint } \\
\end{array}$ \\
\hline & (1) & $(2)$ & $(3)$ & $(4)$ & $(5)$ & (6) \\
\hline Genetic Distance & $\begin{array}{l}-0.02 \\
(0.01)\end{array}$ & $\begin{array}{c}0.19^{* * *} \\
(0.01)\end{array}$ & $\begin{array}{c}0.19^{* * *} \\
(0.01)\end{array}$ & $\begin{array}{c}0.19^{* * *} \\
(0.03)\end{array}$ & $\begin{array}{c}0.26^{* * *} \\
(0.02)\end{array}$ & $\begin{array}{c}0.29 * * * \\
(0.03)\end{array}$ \\
\hline Linguistic Distance & $\begin{array}{c}0.21^{* * *} \\
(0.03)\end{array}$ & $\begin{array}{c}0.29 * * * \\
(0.02)\end{array}$ & $\begin{array}{c}0.03 \\
(0.02)\end{array}$ & $\begin{array}{c}0.28^{* * *} \\
(0.01)\end{array}$ & $\begin{array}{l}0.10^{*} \\
(0.05)\end{array}$ & $\begin{array}{c}0.36^{* * *} \\
(0.04)\end{array}$ \\
\hline Religious Distance & $\begin{array}{c}-0.08^{* *} \\
(0.04)\end{array}$ & $\begin{array}{c}0.23^{* * *} \\
(0.03)\end{array}$ & $\begin{array}{c}0.31^{* * *} \\
(0.01)\end{array}$ & $\begin{array}{c}0.10^{* * *} \\
(0.01)\end{array}$ & $\begin{array}{c}0.39^{* * *} \\
(0.01)\end{array}$ & $\begin{array}{c}0.30^{* * *} \\
(0.02)\end{array}$ \\
\hline Additional Distances & Yes & Yes & Yes & Yes & Yes & Yes \\
\hline Adjusted- $R^{2}$ & 0.48 & 0.78 & 0.50 & 0.56 & 0.61 & 0.60 \\
\hline Observations & 58 & 58 & 58 & 58 & 58 & 58 \\
\hline
\end{tabular}

Notes: This table shows the partial correlation between each of Hofstede's cultural dimensions and genetic distance, when one of the countries in each pair is the United States, accounting for linguistic and religious distances and all the control variables. Coefficients are standardized betas. Two-way clustered standard errors in parentheses. *** denotes statistical significance at the $1 \%$ level, ${ }^{* *}$ at the $5 \%$ level, and $*$ at the $10 \%$ level, all for two-sided hypothesis tests.

Table B.2: Regressions when one of the countries is the United States (WVS)

\begin{tabular}{|c|c|c|c|c|c|c|c|c|c|c|c|c|c|c|}
\hline & \multicolumn{14}{|c|}{ WVS Cultural measures } \\
\hline & $\begin{array}{l}\text { WVS } \\
(1)\end{array}$ & $\begin{array}{l}\text { TRV } \\
(2)\end{array}$ & $\begin{array}{l}\text { SSV } \\
(3)\end{array}$ & $\begin{array}{c}\text { Trust } \\
(4)\end{array}$ & $\begin{array}{l}\text { OBD } \\
(5)\end{array}$ & $\begin{array}{c}\mathrm{HW} \\
(6)\end{array}$ & $\begin{array}{l}\mathrm{FT} \\
(7)\end{array}$ & $\begin{array}{l}\text { WL } \\
(8)\end{array}$ & $\begin{array}{l}\text { CHT } \\
(9)\end{array}$ & $\begin{array}{l}\text { SCK } \\
(10)\end{array}$ & $\begin{array}{c}\text { EQY } \\
(11)\end{array}$ & $\begin{array}{c}\text { MKO } \\
(12)\end{array}$ & $\begin{array}{l}\text { TOL } \\
(13)\end{array}$ & $\begin{array}{l}\text { PET } \\
(14)\end{array}$ \\
\hline Genetic Distance & $\begin{array}{c}-0.44^{* * *} \\
(0.06)\end{array}$ & $\begin{array}{c}0.47^{* * *} \\
(0.05)\end{array}$ & $\begin{array}{c}0.30^{* * *} \\
(0.05)\end{array}$ & $\begin{array}{c}0.35^{* * *} \\
(0.08)\end{array}$ & $\begin{array}{c}0.15^{* * *} \\
(0.03)\end{array}$ & $\begin{array}{c}0.11^{* * *} \\
(0.04)\end{array}$ & $\begin{array}{c}0.10^{* * *} \\
(0.02)\end{array}$ & $\begin{array}{c}-0.29 * * * \\
(0.07)\end{array}$ & $\begin{array}{c}0.10^{* * *} \\
(0.02)\end{array}$ & $\begin{array}{c}0.12^{* * *} \\
(0.03)\end{array}$ & $\begin{array}{c}-0.39 * * * \\
(0.06)\end{array}$ & $\begin{array}{c}0.15 \\
(0.09)\end{array}$ & $\begin{array}{c}-0.26^{* *} \\
(0.13)\end{array}$ & $\begin{array}{c}0.05 \\
(0.09)\end{array}$ \\
\hline Linguistic Distance & $\begin{array}{l}-0.01 \\
(0.08)\end{array}$ & $\begin{array}{c}0.05 \\
(0.09)\end{array}$ & $\begin{array}{c}0.09^{* * *} \\
(0.02)\end{array}$ & $\begin{array}{l}-0.03 \\
(0.12)\end{array}$ & $\begin{array}{c}-0.12^{* * *} \\
(0.02)\end{array}$ & $\begin{array}{l}-0.08 \\
(0.07)\end{array}$ & $\begin{array}{c}-0.04^{* * *} \\
(0.01)\end{array}$ & $\begin{array}{c}0.01 \\
(0.07)\end{array}$ & $\begin{array}{c}0.16^{* * *} \\
(0.04)\end{array}$ & $\begin{array}{c}0.14^{* * *} \\
(0.04)\end{array}$ & $\begin{array}{c}-0.14^{* * *} \\
(0.05)\end{array}$ & $\begin{array}{l}-0.05 \\
(0.16)\end{array}$ & $\begin{array}{c}0.00 \\
(0.03)\end{array}$ & $\begin{array}{c}0.01 \\
(0.09)\end{array}$ \\
\hline Religious Distance & $\begin{array}{c}-0.18^{* * *} \\
(0.07)\end{array}$ & $\begin{array}{c}0.12 \\
(0.07)\end{array}$ & $\begin{array}{c}0.61^{* * *} \\
(0.03)\end{array}$ & $\begin{array}{c}0.11 \\
(0.12)\end{array}$ & $\begin{array}{c}-0.48^{* * *} \\
(0.08)\end{array}$ & $\begin{array}{c}0.22^{* * *} \\
(0.06)\end{array}$ & $\begin{array}{c}-0.12^{* *} \\
(0.05)\end{array}$ & $\begin{array}{c}-0.08^{* * *} \\
(0.02)\end{array}$ & $\begin{array}{l}-0.00 \\
(0.02)\end{array}$ & $\begin{array}{l}-0.03 \\
(0.03)\end{array}$ & $\begin{array}{l}-0.13 \\
(0.09)\end{array}$ & $\begin{array}{c}0.13 \\
(0.10)\end{array}$ & $\begin{array}{c}0.17^{* * *} \\
(0.02)\end{array}$ & $\begin{array}{c}0.39 * * * \\
(0.02)\end{array}$ \\
\hline Additional Distances & Yes & Yes & Yes & Yes & Yes & Yes & Yes & Yes & Yes & Yes & Yes & Yes & Yes & Yes \\
\hline Adjusted- $R^{2}$ & 0.34 & 0.48 & 0.52 & 0.34 & 0.73 & 0.68 & 0.46 & 0.40 & 0.19 & 0.20 & 0.39 & 0.29 & 0.57 & 0.36 \\
\hline Observations & 83 & 83 & 83 & 88 & 61 & 54 & 64 & 83 & 85 & 85 & 75 & 73 & 86 & 88 \\
\hline
\end{tabular}


Table B.3: Relative Cultural and Relative Genetic Distances

\begin{tabular}{|c|c|c|c|c|c|c|}
\hline & \multicolumn{6}{|c|}{ Hofstede Cultural Dimensions Relative to US (OLS) } \\
\hline & $\begin{array}{c}\text { Power } \\
\text { Distance }\end{array}$ & Individualism & $\begin{array}{l}\text { Competition } \\
\text { Cooperation }\end{array}$ & $\begin{array}{l}\text { Uncertainty } \\
\text { Avoidance }\end{array}$ & $\begin{array}{l}\text { Long-Term } \\
\text { Orientation }\end{array}$ & $\begin{array}{c}\text { Indulgence } \\
\text { Restraint }\end{array}$ \\
\hline & $(1)$ & $(2)$ & $(3)$ & $(4)$ & $(5)$ & $(6)$ \\
\hline $\begin{array}{l}\text { Genetic Distance } \\
\text { Relative to US }\end{array}$ & $\begin{array}{c}0.05 \\
(0.06)\end{array}$ & $\begin{array}{c}0.23^{* * *} \\
(0.06)\end{array}$ & $\begin{array}{l}-0.02 \\
(0.04)\end{array}$ & $\begin{array}{l}-0.01 \\
(0.02)\end{array}$ & $\begin{array}{c}0.10^{* *} \\
(0.05)\end{array}$ & $\begin{array}{l}-0.01 \\
(0.04)\end{array}$ \\
\hline $\begin{array}{l}\text { Adjusted- } R^{2} \\
\text { Observations }\end{array}$ & $\begin{array}{l}0.00 \\
1830\end{array}$ & $\begin{array}{l}0.05 \\
1830\end{array}$ & $\begin{array}{l}0.00 \\
1830\end{array}$ & $\begin{array}{l}0.00 \\
1830\end{array}$ & $\begin{array}{l}0.01 \\
1830\end{array}$ & $\begin{array}{l}0.00 \\
1830\end{array}$ \\
\hline
\end{tabular}

Notes: This table shows the correlation between each Hofstede's cultural dimension relative to US and genetic distance relative to US. Coefficients are standardized betas. Two-way clustered standard errors in parentheses. *** denotes statistical significance at the $1 \%$ level, ${ }^{* *}$ at the $5 \%$ level, and ${ }^{*}$ at the $10 \%$ level, all for two-sided hypothesis tests.

Table B.4: Relative Cultural and Relative Genetic Distances

\begin{tabular}{|c|c|c|c|c|c|c|}
\hline & \multicolumn{6}{|c|}{ Hofstede Cultural Dimensions Relative to US (OLS) } \\
\hline & $\begin{array}{c}\text { Power } \\
\text { Distance }\end{array}$ & Individualism & $\begin{array}{l}\text { Competition } \\
\text { Cooperation }\end{array}$ & $\begin{array}{c}\text { Uncertainty } \\
\text { Avoidance }\end{array}$ & $\begin{array}{l}\text { Long-Term } \\
\text { Orientation }\end{array}$ & $\begin{array}{c}\text { Indulgence } \\
\text { Restraint }\end{array}$ \\
\hline & (1) & $(2)$ & $(3)$ & (4) & (5) & (6) \\
\hline Genetic Distance & -0.03 & 0.14 & -0.04 & -0.03 & -0.03 & 0.04 \\
\hline Relative to US & $(0.04)$ & $(0.09)$ & $(0.08)$ & $(0.02)$ & $(0.05)$ & $(0.09)$ \\
\hline \multirow[t]{2}{*}{ Linguistic Distance } & 0.12 & 0.27 & 0.03 & $0.40^{* * *}$ & $0.12^{* *}$ & 0.11 \\
\hline & $(0.11)$ & $(0.17)$ & $(0.05)$ & $(0.12)$ & $(0.06)$ & $(0.09)$ \\
\hline \multirow[t]{2}{*}{ Religious Distance } & 0.05 & 0.07 & 0.04 & 0.06 & 0.08 & 0.08 \\
\hline & $(0.03)$ & $(0.05)$ & $(0.05)$ & $(0.08)$ & $(0.10)$ & $(0.07)$ \\
\hline Country FE & Yes & Yes & Yes & Yes & Yes & Yes \\
\hline Additional Distances & Yes & Yes & Yes & Yes & Yes & Yes \\
\hline Adjusted- $R^{2}$ & 0.44 & 0.44 & 0.48 & 0.25 & 0.37 & 0.32 \\
\hline Observations & 1653 & 1653 & 1653 & 1653 & 1653 & 1653 \\
\hline
\end{tabular}

Notes: This table shows the correlation between each Hofstede's cultural dimension relative to US and genetic distance relative to US with all controls including in the regressions. Coefficients are standardized betas. Two-way clustered standard errors in parentheses. $* * *$ denotes statistical significance at the $1 \%$ level, $* *$ at the $5 \%$ level, and $*$ at the $10 \%$ level, all for two-sided hypothesis tests. 
Table B.5: Relative Cultural and Relative Genetic Distances

\begin{tabular}{|c|c|c|c|c|c|c|}
\hline & \multicolumn{6}{|c|}{ Hofstede Cultural Dimensions Relative to US (OLS) } \\
\hline & $\begin{array}{c}\text { Power } \\
\text { Distance }\end{array}$ & Individualism & $\begin{array}{l}\text { Competition } \\
\text { Cooperation }\end{array}$ & $\begin{array}{c}\text { Uncertainty } \\
\text { Avoidance }\end{array}$ & $\begin{array}{l}\text { Long-Term } \\
\text { Orientation }\end{array}$ & $\begin{array}{c}\text { Indulgence } \\
\text { Restraint }\end{array}$ \\
\hline & $(1)$ & $(2)$ & $(3)$ & $(4)$ & $(5)$ & $(6)$ \\
\hline Genetic Distance & -0.04 & 0.12 & -0.04 & -0.02 & -0.03 & 0.02 \\
\hline Relative to US & $(0.03)$ & $(0.09)$ & $(0.07)$ & $(0.04)$ & $(0.05)$ & $(0.06)$ \\
\hline Linguistic Distance & 0.17 & $0.38^{* *}$ & $0.19^{* *}$ & $0.22^{*}$ & 0.10 & $0.45^{* * *}$ \\
\hline Relative to the US & $(0.12)$ & $(0.16)$ & $(0.08)$ & $(0.12)$ & $(0.06)$ & $(0.11)$ \\
\hline Religious Distance & 0.03 & $0.14^{* *}$ & -0.01 & $-0.05^{* *}$ & 0.02 & 0.11 \\
\hline Relative to the US & $(0.04)$ & $(0.06)$ & $(0.02)$ & $(0.02)$ & $(0.06)$ & $(0.08)$ \\
\hline Country FE & Yes & Yes & Yes & Yes & Yes & Yes \\
\hline Additional Distances & Yes & Yes & Yes & Yes & Yes & Yes \\
\hline Adjusted- $R^{2}$ & 0.44 & 0.45 & 0.48 & 0.23 & 0.37 & 0.35 \\
\hline Observations & 1653 & 1653 & 1653 & 1653 & 1653 & 1653 \\
\hline
\end{tabular}

Notes: This table shows the correlation between each Hofstede's cultural dimension relative to US and genetic distance relative to US with all controls including in the regressions, including linguistic distance relative to US and religious distance relative to US. Coefficients are standardized betas. Two-way clustered standard errors in parentheses. *** denotes statistical significance at the $1 \%$ level, ${ }^{* *}$ at the $5 \%$ level, and ${ }^{*}$ at the $10 \%$ level, all for two-sided hypothesis tests.

Table B.6: Relative Cultural and Relative Genetic Distances

\begin{tabular}{|c|c|c|c|c|c|c|}
\hline & \multicolumn{6}{|c|}{ Hofstede Cultural Dimensions Relative to US (OLS) } \\
\hline & $\begin{array}{c}\text { Power } \\
\text { Distance }\end{array}$ & Individualism & $\begin{array}{r}\text { Competition } \\
\text { Cooperation }\end{array}$ & $\begin{array}{c}\text { Uncertainty } \\
\text { Avoidance }\end{array}$ & $\begin{array}{l}\text { Long-Term } \\
\text { Orientation }\end{array}$ & $\begin{array}{c}\text { Indulgence } \\
\text { Restraint }\end{array}$ \\
\hline & (1) & $(2)$ & (3) & (4) & $(5)$ & (6) \\
\hline Genetic Distance & $\begin{array}{c}0.08 \\
(0.08)\end{array}$ & $\begin{array}{l}0.31^{* *} \\
(0.12)\end{array}$ & $\begin{array}{c}0.04 \\
(0.08)\end{array}$ & $\begin{array}{l}-0.00 \\
(0.08)\end{array}$ & $\begin{array}{l}-0.06 \\
(0.10)\end{array}$ & $\begin{array}{c}0.03 \\
(0.08)\end{array}$ \\
\hline Linguistic Distance & $\begin{array}{c}0.12 \\
(0.10)\end{array}$ & $\begin{array}{l}0.29^{*} \\
(0.17)\end{array}$ & $\begin{array}{c}0.03 \\
(0.05)\end{array}$ & $\begin{array}{c}0.40^{* * *} \\
(0.13)\end{array}$ & $\begin{array}{c}0.12^{* *} \\
(0.06)\end{array}$ & $\begin{array}{c}0.11 \\
(0.09)\end{array}$ \\
\hline Religious Distance & $\begin{array}{c}0.04 \\
(0.03)\end{array}$ & $\begin{array}{c}0.05 \\
(0.04)\end{array}$ & $\begin{array}{c}0.03 \\
(0.05)\end{array}$ & $\begin{array}{c}0.06 \\
(0.08)\end{array}$ & $\begin{array}{c}0.08 \\
(0.10)\end{array}$ & $\begin{array}{c}0.08 \\
(0.08)\end{array}$ \\
\hline Country FE & Yes & Yes & Yes & Yes & Yes & Yes \\
\hline Additional Distances & Yes & Yes & Yes & Yes & Yes & Yes \\
\hline Adjusted- $R^{2}$ & 0.44 & 0.45 & 0.48 & 0.25 & 0.37 & 0.32 \\
\hline Observations & 1653 & 1653 & 1653 & 1653 & 1653 & 1653 \\
\hline
\end{tabular}

Notes: This table shows the correlation between each Hofstede's cultural dimension relative to US and genetic distance relative to US with all controls including in the regressions, including linguistic distance and religious pairwise distances. Coefficients are standardized betas. Two-way clustered standard errors in parentheses. *** denotes statistical significance at the $1 \%$ level, $* *$ at the $5 \%$ level, and * at the $10 \%$ level, all for two-sided hypothesis tests. 
Table B.7: Relative Cultural and Relative Genetic Distances

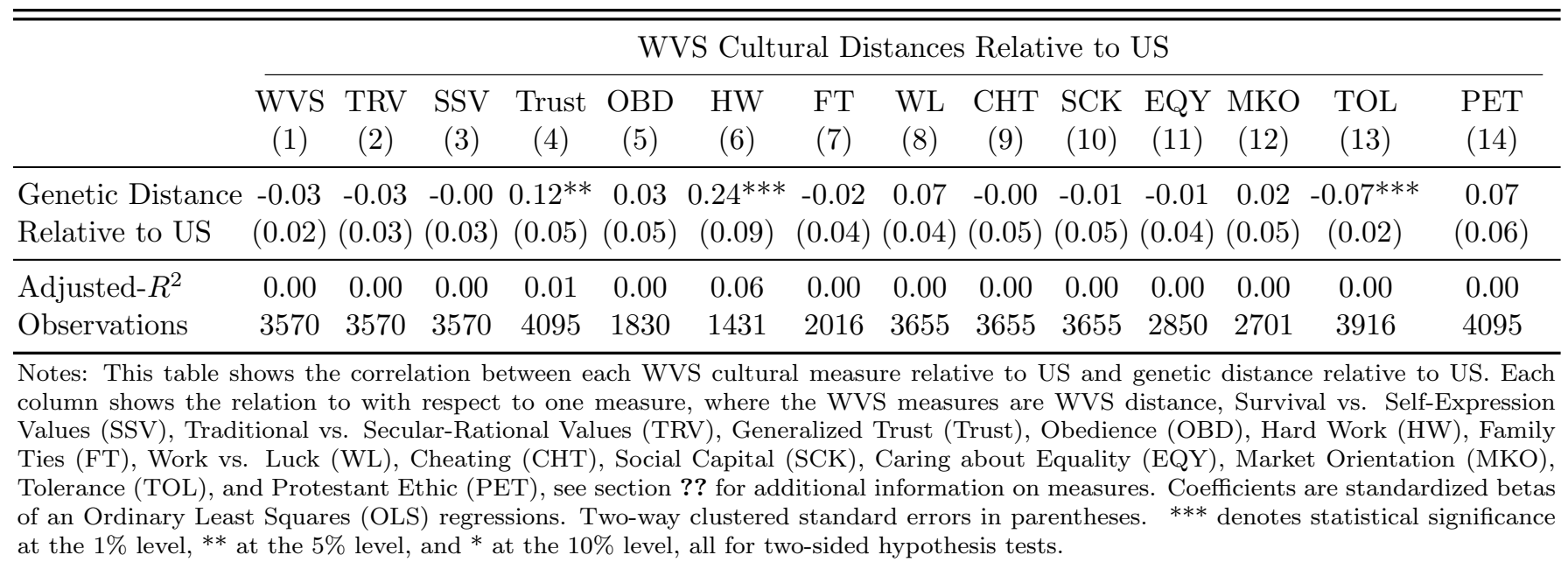


Table B.8: Relative Cultural and Relative Genetic Distances

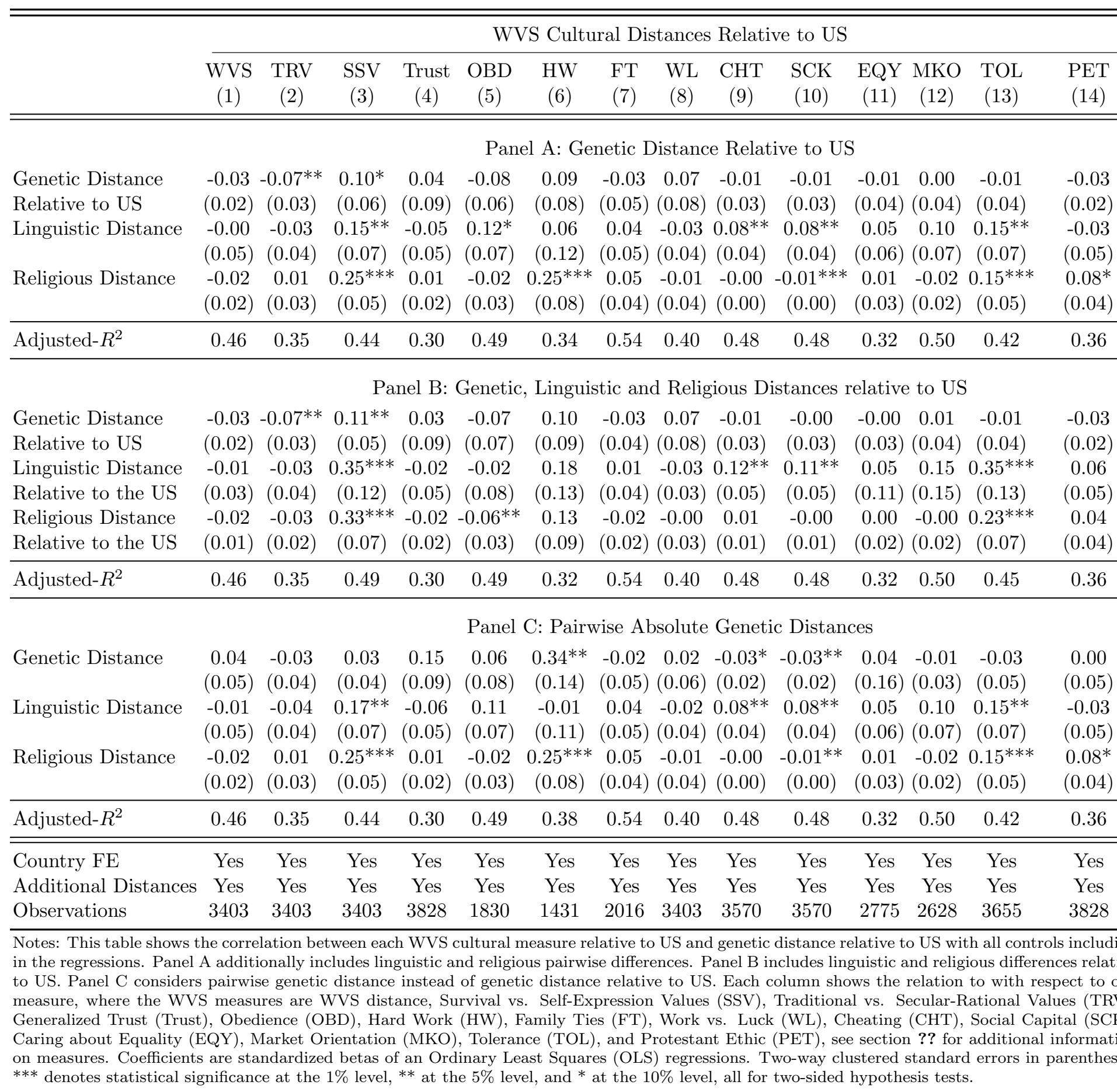




\section{Income and Cultural Differences}

Table C.1: Income Differences and Genetic Distances

\begin{tabular}{|c|c|c|c|c|c|c|c|c|}
\hline & \multicolumn{8}{|c|}{ Differences in log per capita income (1995) } \\
\hline & $(1)$ & $(2)$ & (3) & (4) & (5) & (6) & (7) & (8) \\
\hline Genetic Distance & $\begin{array}{c}0.22^{* * *} \\
(0.05)\end{array}$ & & $\begin{array}{c}0.04 \\
(0.05)\end{array}$ & $\begin{array}{c}0.17 \\
(0.11)\end{array}$ & $\begin{array}{r}0.13^{* *} \\
(0.06)\end{array}$ & $\begin{array}{l}0.14^{* *} \\
(0.07)\end{array}$ & $\begin{array}{l}0.15^{* *} \\
(0.06)\end{array}$ & $\begin{array}{r}0.15^{* *} \\
(0.07)\end{array}$ \\
\hline $\begin{array}{l}\text { Genetic Distance } \\
\text { relative to US }\end{array}$ & & $\begin{array}{c}0.32^{* * *} \\
(0.06)\end{array}$ & $\begin{array}{c}0.29^{* * *} \\
(0.06)\end{array}$ & $\begin{array}{c}0.24^{* * *} \\
(0.09)\end{array}$ & $\begin{array}{c}0.23^{* * *} \\
(0.08)\end{array}$ & $\begin{array}{c}0.21^{* * * *} \\
(0.07)\end{array}$ & $\begin{array}{c}0.21^{* * *} \\
(0.07)\end{array}$ & $\begin{array}{c}0.21^{* * *} \\
(0.07)\end{array}$ \\
\hline Linguistic Distance & & & & & & $\begin{array}{l}-0.01 \\
(0.04)\end{array}$ & & $\begin{array}{l}-0.02 \\
(0.04)\end{array}$ \\
\hline Religious Distance & & & & & & $\begin{array}{c}0.12^{* * *} \\
(0.04)\end{array}$ & & $\begin{array}{c}0.06 \\
(0.04)\end{array}$ \\
\hline $\begin{array}{l}\text { Linguistic Distance } \\
\text { relative to the US }\end{array}$ & & & & & & & $\begin{array}{c}0.10 \\
(0.07)\end{array}$ & $\begin{array}{c}0.10 \\
(0.07)\end{array}$ \\
\hline Religious Distance & & & & & & & $0.11^{* * *}$ & 0.07 \\
\hline relative to the US & & & & & & & $(0.04)$ & $(0.05)$ \\
\hline Country FE & No & No & No & Yes & Yes & Yes & Yes & Yes \\
\hline Geo Controls & No & No & No & No & Yes & Yes & Yes & Yes \\
\hline Historical Controls & No & No & No & No & Yes & Yes & Yes & Yes \\
\hline statistics & & & 11.16 & 0.79 & 1.77 & 1.51 & 1.43 & 1.34 \\
\hline significance level & & & 0.00 & 0.38 & 0.18 & 0.22 & 0.23 & 0.25 \\
\hline Adjusted- $R^{2}$ & 0.05 & 0.10 & 0.10 & 0.37 & 0.38 & 0.38 & 0.38 & 0.39 \\
\hline Observations & 11175 & 11175 & 11175 & 11175 & 11175 & 11175 & 11175 & 11175 \\
\hline
\end{tabular}

Notes: This table shows the relationship of income differences between countries with their pairwise genetic distances and genetic distance relative to the frontier for the largest sample of countries. Coefficients are standardized betas. Two-way clustered standard errors in parentheses. $* * *$ denotes statistical significance at the $1 \%$ level, ** at the $5 \%$ level, and * at the $10 \%$ level, all for two-sided hypothesis tests. 
Table C.2: Hofstede Cultural Dimensions and Income (All Controls)

\begin{tabular}{|c|c|c|c|c|c|c|c|c|}
\hline & \multicolumn{8}{|c|}{ differences in log per capita Income, 1995} \\
\hline & (1) & $(2)$ & (3) & (4) & (5) & (6) & (7) & (8) \\
\hline Genetic Distance & 0.09 & 0.06 & 0.09 & 0.09 & 0.09 & 0.09 & 0.08 & 0.06 \\
\hline Relative to US & $(0.09)$ & $(0.07)$ & $(0.07)$ & $(0.09)$ & $(0.10)$ & $(0.07)$ & $(0.10)$ & $(0.07)$ \\
\hline Individualism & & $\begin{array}{c}0.25^{* * *} \\
(0.09)\end{array}$ & & & & & & $\begin{array}{c}0.16 \\
(0.10)\end{array}$ \\
\hline Power Distance & & & $\begin{array}{c}0.42^{* * *} \\
(0.09)\end{array}$ & & & & & $\begin{array}{c}0.28^{* * *} \\
(0.10)\end{array}$ \\
\hline Competition/Cooperation & & & & $\begin{array}{c}0.03 \\
(0.05)\end{array}$ & & & & $\begin{array}{c}0.01 \\
(0.05)\end{array}$ \\
\hline Uncertainty Avoidance & & & & & $\begin{array}{c}0.07 \\
(0.05)\end{array}$ & & & $\begin{array}{c}0.05 \\
(0.04)\end{array}$ \\
\hline Long-Term Orientation & & & & & & $\begin{array}{l}-0.03 \\
(0.09)\end{array}$ & & $\begin{array}{c}0.02 \\
(0.11)\end{array}$ \\
\hline Indulgence/Restraint & & & & & & & $\begin{array}{l}-0.10 \\
(0.07)\end{array}$ & $\begin{array}{l}-0.04 \\
(0.07)\end{array}$ \\
\hline Individualism & & 0.00 & & & & & & 0.00 \\
\hline Relative to US & & $(0.00)$ & & & & & & $(0.00)$ \\
\hline Power Distance & & & -0.13 & & & & & -0.08 \\
\hline Relative to US & & & $(0.09)$ & & & & & $(0.09)$ \\
\hline Competition/Cooperation & & & & -0.04 & & & & -0.01 \\
\hline Relative to US & & & & $(0.04)$ & & & & $(0.04)$ \\
\hline Uncertainty Avoidance & & & & & -0.04 & & & $-0.08^{*}$ \\
\hline Relative to US & & & & & $(0.04)$ & & & $(0.04)$ \\
\hline Long-Term Orientation & & & & & & -0.01 & & -0.06 \\
\hline Relative to US & & & & & & $(0.10)$ & & $(0.09)$ \\
\hline Indulgence/Restraint & & & & & & & $0.31^{* * *}$ & $0.22^{* *}$ \\
\hline Relative to US & & & & & & & $(0.10)$ & $(0.10)$ \\
\hline Linguistic Distance & $0.17^{* *}$ & 0.11 & 0.08 & $0.17^{* *}$ & $0.16^{* *}$ & $0.17^{* *}$ & $0.17^{* *}$ & 0.09 \\
\hline & $(0.08)$ & $(0.07)$ & $(0.07)$ & $(0.08)$ & $(0.08)$ & $(0.08)$ & $(0.09)$ & $(0.08)$ \\
\hline Religious Distance & -0.06 & -0.02 & -0.08 & -0.05 & -0.06 & -0.05 & -0.04 & -0.02 \\
\hline & $(0.13)$ & $(0.13)$ & $(0.12)$ & $(0.13)$ & $(0.13)$ & $(0.14)$ & $(0.13)$ & $(0.12)$ \\
\hline Linguistic Distance & $0.15^{*}$ & 0.07 & 0.08 & $0.15^{*}$ & $0.15^{*}$ & $0.15^{*}$ & 0.06 & -0.01 \\
\hline Relative to the US & $(0.09)$ & $(0.08)$ & $(0.09)$ & $(0.08)$ & $(0.08)$ & $(0.09)$ & $(0.10)$ & $(0.09)$ \\
\hline Religious Distance & 0.13 & 0.08 & 0.11 & 0.13 & 0.14 & 0.13 & 0.10 & 0.05 \\
\hline Relative to the US & $(0.11)$ & $(0.11)$ & $(0.10)$ & $(0.11)$ & $(0.11)$ & $(0.11)$ & $(0.10)$ & $(0.10)$ \\
\hline Country FE & Yes & Yes & Yes & Yes & Yes & Yes & Yes & Yes \\
\hline Other Controls & Yes & Yes & Yes & Yes & Yes & Yes & Yes & Yes \\
\hline Adjusted- $R^{2}$ & 0.48 & 0.52 & 0.54 & 0.49 & 0.49 & 0.49 & 0.52 & 0.58 \\
\hline Observations & 1653 & 1653 & 1653 & 1653 & 1653 & 1653 & 1653 & 1653 \\
\hline
\end{tabular}

Notes: This table explores the direct and barrier effects of Hofstede's cultural values by running a horse race between absolute and relative cultural dizstances, including linguistic and religious distances. Coefficients are standardized betas of an Ordinary Least Squares (OLS) regression after accounting for country fixed effects, geographical differences, pairwise continental fixed effects. Two-way clustered standard errors in parentheses. $* * *$ denotes statistical significance at the $1 \%$ level, $* *$ at the $5 \%$ level, 
Table C.3: WVS Cultural Dimensions and Income (All Controls)

\begin{tabular}{|c|c|c|c|c|c|c|c|c|c|c|c|c|c|c|}
\hline & \multicolumn{14}{|c|}{ Differences in log per capita income (1995) } \\
\hline & $\begin{array}{c}\text { WVS } \\
(1)\end{array}$ & $\begin{array}{c}\text { TRV } \\
(2)\end{array}$ & $\begin{array}{c}\text { SSV } \\
(3)\end{array}$ & $\begin{array}{c}\text { Trust } \\
(4)\end{array}$ & $\begin{array}{c}\text { OBD } \\
(5)\end{array}$ & $\begin{array}{c}\text { HW } \\
(6)\end{array}$ & $\begin{array}{l}\mathrm{FT} \\
(7)\end{array}$ & $\begin{array}{l}\text { WL } \\
(8)\end{array}$ & $\begin{array}{c}\text { CHT } \\
(9)\end{array}$ & $\begin{array}{c}\text { SCK } \\
(10)\end{array}$ & $\begin{array}{c}\text { EQY } \\
(11)\end{array}$ & $\begin{array}{c}\mathrm{MKO} \\
(12)\end{array}$ & $\begin{array}{l}\text { TOL } \\
(13)\end{array}$ & $\begin{array}{c}\text { PET } \\
(14)\end{array}$ \\
\hline Genetic Distance & $0.14^{*}$ & $0.16^{* *}$ & 0.11 & $0.17^{* *}$ & 0.06 & 0.05 & 0.07 & $0.12^{*}$ & $0.16^{*}$ & $0.16^{*}$ & $0.15^{*}$ & 0.13 & $0.16^{*}$ & $0.17^{* *}$ \\
\hline Relative to US & $(0.08)$ & $(0.08)$ & $(0.07)$ & $(0.08)$ & $(0.06)$ & $(0.06)$ & $(0.08)$ & $(0.07)$ & $(0.08)$ & $(0.08)$ & $(0.08)$ & $(0.08)$ & $(0.09)$ & $(0.07)$ \\
\hline Absolute Distance & $\begin{array}{c}0.23^{* * *} \\
(0.07)\end{array}$ & $\begin{array}{c}0.04 \\
(0.03)\end{array}$ & $\begin{array}{c}0.13^{* * *} \\
(0.03)\end{array}$ & $\begin{array}{c}0.22^{* * *} \\
(0.08)\end{array}$ & $\begin{array}{c}0.25 \\
(0.17)\end{array}$ & $\begin{array}{c}0.27^{* * *} \\
(0.05)\end{array}$ & $\begin{array}{l}0.11^{*} \\
(0.06)\end{array}$ & $\begin{array}{c}0.01 \\
(0.01)\end{array}$ & $\begin{array}{l}-0.01 \\
(0.01)\end{array}$ & $\begin{array}{l}-0.00 \\
(0.00)\end{array}$ & $\begin{array}{l}0.02^{*} \\
(0.01)\end{array}$ & $\begin{array}{c}0.01 \\
(0.01)\end{array}$ & $\begin{array}{l}0.14^{*} \\
(0.07)\end{array}$ & $\begin{array}{c}-0.04^{* * *} \\
(0.01)\end{array}$ \\
\hline Relative Distance & $\begin{array}{c}-0.12^{* * *} \\
(0.03)\end{array}$ & $\begin{array}{l}-0.01 \\
(0.02)\end{array}$ & $\begin{array}{c}0.00 \\
(0.03)\end{array}$ & $\begin{array}{c}-0.08^{*} \\
(0.04)\end{array}$ & $\begin{array}{l}-0.12 \\
(0.11)\end{array}$ & $\begin{array}{l}-0.05 \\
(0.04)\end{array}$ & $\begin{array}{l}-0.03 \\
(0.02)\end{array}$ & $\begin{array}{c}-0.01 \\
(0.01)\end{array}$ & $\begin{array}{c}0.02 \\
(0.02)\end{array}$ & $\begin{array}{c}0.01 \\
(0.01)\end{array}$ & $\begin{array}{l}-0.00 \\
(0.01)\end{array}$ & $\begin{array}{c}0.00 \\
(0.00)\end{array}$ & $\begin{array}{c}-0.08^{*} \\
(0.04)\end{array}$ & $\begin{array}{c}-0.00 \\
(0.01)\end{array}$ \\
\hline Linguistic Distance & $\begin{array}{c}0.03 \\
(0.04)\end{array}$ & $\begin{array}{c}0.04 \\
(0.04)\end{array}$ & $\begin{array}{l}-0.01 \\
(0.04)\end{array}$ & $\begin{array}{c}0.03 \\
(0.04)\end{array}$ & $\begin{array}{l}-0.02 \\
(0.05)\end{array}$ & $\begin{array}{c}0.17^{* *} \\
(0.07)\end{array}$ & $\begin{array}{l}-0.00 \\
(0.04)\end{array}$ & $\begin{array}{c}0.02 \\
(0.04)\end{array}$ & $\begin{array}{c}0.04 \\
(0.04)\end{array}$ & $\begin{array}{c}0.04 \\
(0.04)\end{array}$ & $\begin{array}{c}0.04 \\
(0.05)\end{array}$ & $\begin{array}{c}0.05 \\
(0.05)\end{array}$ & $\begin{array}{c}0.03 \\
(0.04)\end{array}$ & $\begin{array}{c}0.04 \\
(0.04)\end{array}$ \\
\hline Religious Distance & $\begin{array}{c}0.10 \\
(0.07)\end{array}$ & $\begin{array}{c}0.07 \\
(0.06)\end{array}$ & $\begin{array}{c}0.11 \\
(0.07)\end{array}$ & $\begin{array}{c}0.11 \\
(0.06)\end{array}$ & $\begin{array}{l}0.14^{*} \\
(0.08)\end{array}$ & $\begin{array}{l}-0.03 \\
(0.08)\end{array}$ & $\begin{array}{c}0.10 \\
(0.08)\end{array}$ & $\begin{array}{c}0.10 \\
(0.07)\end{array}$ & $\begin{array}{l}0.12^{*} \\
(0.07)\end{array}$ & $\begin{array}{l}0.12^{*} \\
(0.07)\end{array}$ & $\begin{array}{c}0.14^{* *} \\
(0.07)\end{array}$ & $\begin{array}{l}0.14^{*} \\
(0.08)\end{array}$ & $\begin{array}{c}0.13^{* *} \\
(0.06)\end{array}$ & $\begin{array}{l}0.13^{*} \\
(0.06)\end{array}$ \\
\hline Linguistic Distance & $0.14^{* * *}$ & $0.18^{* * *}$ & 0.02 & $0.18^{* * *}$ & 0.17 & 0.11 & 0.10 & $0.21^{* * *}$ & $0.19^{* * *}$ & $0.19^{* * *}$ & $0.20 * *$ & $0.19^{* *}$ & $0.14^{* * *}$ & $0.19^{* * *}$ \\
\hline Relative to the US & $(0.05)$ & $(0.06)$ & $(0.06)$ & $(0.06)$ & $(0.14)$ & $(0.09)$ & $(0.10)$ & $(0.07)$ & $(0.06)$ & $(0.06)$ & $(0.09)$ & $(0.09)$ & $(0.05)$ & $(0.06)$ \\
\hline Religious Distance & 0.03 & 0.07 & -0.07 & 0.02 & 0.03 & 0.07 & 0.05 & 0.05 & 0.03 & 0.03 & -0.00 & 0.02 & -0.00 & 0.00 \\
\hline Relative to the US & $(0.07)$ & $(0.07)$ & $(0.07)$ & $(0.07)$ & $(0.09)$ & $(0.08)$ & $(0.09)$ & $(0.08)$ & $(0.07)$ & $(0.07)$ & $(0.07)$ & $(0.08)$ & $(0.07)$ & $(0.07)$ \\
\hline Country FE & Yes & & & & & & & Yes & Yes & Yes & Yes & Yes & Yes & Yes \\
\hline Other Controls & Yes & Yes & Yes & Yes & Yes & Yes & Yes & Yes & Yes & Yes & Yes & Yes & Yes & Yes \\
\hline Adjusted- $R^{2}$ & 0.49 & 0.48 & 0.55 & 0.47 & 0.48 & 0.63 & 0.50 & 0.47 & 0.47 & 0.47 & 0.49 & 0.50 & 0.47 & 0.46 \\
\hline Observations & 3403 & 3403 & 3403 & 3828 & 1830 & 1431 & 2016 & 3403 & 3570 & 3570 & 2775 & 2628 & 3655 & 3828 \\
\hline
\end{tabular}

Notes: This table explores the direct and barrier effects of culture on development based on WVS cultural values. Absolute and relative distance refer to the measure in the column. The WVS measures are WVS distance, Survival vs. Self-Expression Values (SSV), Traditional vs. Secular-Rational Values (TRV), Generalized Trust (Trust), Obedience (OBD), Hard Work (HW), Family Ties (FT), Work vs. Luck (WL), Cheating (CHT), Social Capital (SCK), Caring about Equality (EQY), Market Orientation (MKO), Tolerance (TOL), and Protestant Ethic (PET), see section ?? for additional information on measures. Coefficients are standardized betas of an Ordinary Least Squares (OLS) regression after accounting for country fixed effects, geographical differences, pairwise continental fixed effects. Two-way clustered standard errors in parentheses. ${ }^{* * *}$ denotes statistical significance at the $1 \%$ level, $* *$ at the $5 \%$ level, and * at the $10 \%$ level, all for two-sided hypothesis tests. 
Table C.4: WVS Cultural Dimensions and Income (Country FE-s)

\begin{tabular}{|c|c|c|c|c|c|c|c|c|c|c|c|c|c|c|}
\hline & \multicolumn{14}{|c|}{ Differences in log per capita income (1995) } \\
\hline & \multirow{2}{*}{$\frac{\text { Base }}{(1)}$} & \multicolumn{5}{|c|}{ Absolute } & \multicolumn{5}{|c|}{ Relative } & \multicolumn{3}{|c|}{ Horse Race } \\
\hline & & $(2)$ & (3) & (4) & (5) & (6) & (7) & (8) & (9) & (10) & (11) & $(12)$ & (13) & $(14)$ \\
\hline $\begin{array}{l}\text { Genetic Distance } \\
\text { relative to US }\end{array}$ & $\begin{array}{c}0.29^{* * * *} \\
(0.09)\end{array}$ & $\begin{array}{r}0.20^{* *} \\
(0.08)\end{array}$ & $\begin{array}{c}0.25^{* * *} \\
(0.09)\end{array}$ & $\begin{array}{c}0.22^{* * * *} \\
(0.08)\end{array}$ & $\begin{array}{c}0.19^{* * *} \\
(0.07)\end{array}$ & $\begin{array}{c}0.07 \\
(0.09)\end{array}$ & $\begin{array}{c}0.23^{* * *} \\
(0.08)\end{array}$ & $\begin{array}{c}0.28^{* * *} \\
(0.09)\end{array}$ & $\begin{array}{c}0.22 * * * \\
(0.08)\end{array}$ & $\begin{array}{c}0.22^{* * *} \\
(0.08)\end{array}$ & $\begin{array}{c}0.08 \\
(0.08)\end{array}$ & $\begin{array}{c}0.21^{* * *} \\
(0.08)\end{array}$ & $\begin{array}{c}0.19^{* * * *} \\
(0.07)\end{array}$ & $\begin{array}{c}0.07 \\
(0.08)\end{array}$ \\
\hline WVS cultural dist & & $\begin{array}{c}0.37^{* * *} \\
(0.07)\end{array}$ & & & & & & & & & & $\begin{array}{l}0.21^{* *} \\
(0.09)\end{array}$ & & \\
\hline Traditional/Rational & & & $\begin{array}{c}0.17^{* * *} \\
(0.06)\end{array}$ & & $\begin{array}{c}0.15^{* *} \\
(0.06)\end{array}$ & $\begin{array}{c}0.13^{* *} \\
(0.06)\end{array}$ & & & & & & & $\begin{array}{r}0.17^{* *} \\
(0.07)\end{array}$ & $\begin{array}{r}0.15^{* *} \\
(0.07)\end{array}$ \\
\hline Survival/Selfexpress & & & & $\begin{array}{c}0.39 * * * \\
(0.06)\end{array}$ & $\begin{array}{c}0.38^{* * *} \\
(0.06)\end{array}$ & $\begin{array}{c}0.38^{* * *} \\
(0.06)\end{array}$ & & & & & & & $\begin{array}{c}0.27 \\
(0.18)\end{array}$ & $\begin{array}{c}0.29 \\
(0.18)\end{array}$ \\
\hline Genetic Distance & & & & & & $\begin{array}{l}0.25^{* *} \\
(0.11)\end{array}$ & & & & & $\begin{array}{c}0.28^{* * *} \\
(0.10)\end{array}$ & & & $\begin{array}{r}0.25^{* *} \\
(0.11)\end{array}$ \\
\hline $\begin{array}{l}\text { WVS cultural dist, } \\
\text { relative to US }\end{array}$ & & & & & & & $\begin{array}{c}0.38^{* * *} \\
(0.06)\end{array}$ & & & & & $\begin{array}{c}0.21^{* *} \\
(0.08)\end{array}$ & & \\
\hline $\begin{array}{l}\text { Traditional/Rational, } \\
\text { relative to US }\end{array}$ & & & & & & & & $\begin{array}{l}0.09^{*} \\
(0.05)\end{array}$ & & $\begin{array}{l}0.08^{*} \\
(0.05)\end{array}$ & $\begin{array}{c}0.07 \\
(0.05)\end{array}$ & & $\begin{array}{l}-0.04 \\
(0.05)\end{array}$ & $\begin{array}{l}-0.03 \\
(0.05)\end{array}$ \\
\hline $\begin{array}{l}\text { Survival/Selfexpression, } \\
\text { relative to US }\end{array}$ & & & & & & & & & $\begin{array}{c}0.36^{* * *} \\
(0.06)\end{array}$ & $\begin{array}{c}0.36^{* * *} \\
(0.06)\end{array}$ & $\begin{array}{c}0.36^{* * *} \\
(0.06)\end{array}$ & & $\begin{array}{c}0.10 \\
(0.21)\end{array}$ & $\begin{array}{c}0.08 \\
(0.21)\end{array}$ \\
\hline Country FE & Yes & Yes & Yes & Yes & Yes & Yes & Yes & Yes & Yes & Yes & Yes & Yes & Yes & Yes \\
\hline Adjusted- $R^{2}$ & 0.36 & 0.46 & 0.38 & 0.46 & 0.48 & 0.49 & 0.46 & 0.37 & 0.46 & 0.46 & 0.48 & 0.48 & 0.48 & 0.49 \\
\hline Observations & 4095 & 4095 & 4095 & 4095 & 4095 & 4095 & 4095 & 4095 & 4095 & 4095 & 4095 & 4095 & 4095 & 4095 \\
\hline
\end{tabular}

Table C.5: WVS Cultural Dimensions and Income (Geo and Historical Controls)

\begin{tabular}{|c|c|c|c|c|c|c|c|c|c|c|c|c|c|c|}
\hline & \multicolumn{14}{|c|}{ Differences in log per capita income (1995) } \\
\hline & \multirow{2}{*}{$\frac{\text { Base }}{(1)}$} & \multicolumn{5}{|c|}{ Absolute } & \multicolumn{5}{|c|}{ Relative } & \multicolumn{3}{|c|}{ Horse Race } \\
\hline & & $(2)$ & $(3)$ & $(4)$ & $(5)$ & $(6)$ & $(7)$ & $(8)$ & $(9)$ & $(10)$ & $(11)$ & $(12)$ & $(13)$ & $(14)$ \\
\hline $\begin{array}{l}\text { Genetic Distance } \\
\text { relative to US }\end{array}$ & $\begin{array}{c}0.25^{* * *} \\
(0.09)\end{array}$ & $\begin{array}{c}0.22 * * * \\
(0.08)\end{array}$ & $\begin{array}{c}{ }^{*} 0.25^{* * *} \\
(0.08)\end{array}$ & $\begin{array}{c}* 0.19 * * * \\
(0.07)\end{array}$ & $\begin{array}{l}0.20^{* *} \\
(0.10)\end{array}$ & $\begin{array}{c}0.08 \\
(0.08)\end{array}$ & $\begin{array}{c}0.23^{* * *} \\
(0.08)\end{array}$ & $\begin{array}{c}0.25^{* * *} \\
(0.10)\end{array}$ & $\begin{array}{c}* 0.20^{* * * *} \\
(0.07)\end{array}$ & $\begin{array}{c}0.20^{* * *} \\
(0.07)\end{array}$ & $\begin{array}{c}0.07 \\
(0.09)\end{array}$ & $\begin{array}{c}0.22^{* * *} \\
(0.07)\end{array}$ & $\begin{array}{c}0.19^{* * *} \\
(0.07)\end{array}$ & $\begin{array}{c}0.08 \\
(0.08)\end{array}$ \\
\hline WVS cultural dist & & $\begin{array}{c}0.39 * * * \\
(0.07)\end{array}$ & & & & & & & & & & $\begin{array}{c}0.25^{* * *} \\
(0.08)\end{array}$ & & \\
\hline Traditional/Rational & & & $\begin{array}{c}0.17^{* * *} \\
(0.06)\end{array}$ & & $\begin{array}{c}0.16^{* * *} \\
(0.06)\end{array}$ & $\begin{array}{l}0.15^{* *} \\
(0.06)\end{array}$ & & & & & & & $\begin{array}{c}0.19^{* * *} \\
(0.07)\end{array}$ & $\begin{array}{c}0.17^{* * *} \\
(0.06)\end{array}$ \\
\hline Survival/Selfexpress & & & & $\begin{array}{c}0.38^{* * *} \\
(0.06)\end{array}$ & $\begin{array}{c}0.38^{* * * *} \\
(0.06)\end{array}$ & $\begin{array}{c}0.38^{* * *} \\
(0.06)\end{array}$ & & & & & & & $\begin{array}{c}0.25 \\
(0.17)\end{array}$ & $\begin{array}{c}0.25 \\
(0.18)\end{array}$ \\
\hline Genetic Distance & & & & & & $\begin{array}{l}0.25^{* *} \\
(0.10)\end{array}$ & & & & & $\begin{array}{c}0.28^{* *} \\
(0.11)\end{array}$ & & & $\begin{array}{l}0.24^{* *} \\
(0.10)\end{array}$ \\
\hline $\begin{array}{l}\text { WVS cultural dist, } \\
\text { relative to US }\end{array}$ & & & & & & & $\begin{array}{c}0.37^{* * *} \\
(0.06)\end{array}$ & & & & & $\begin{array}{l}0.18^{* *} \\
(0.08)\end{array}$ & & \\
\hline $\begin{array}{l}\text { Traditional/Rational, } \\
\text { relative to US }\end{array}$ & & & & & & & & $\begin{array}{l}0.08^{*} \\
(0.05)\end{array}$ & & $\begin{array}{c}0.07 \\
(0.05)\end{array}$ & $\begin{array}{c}0.07 \\
(0.05)\end{array}$ & & $\begin{array}{l}-0.04 \\
(0.05)\end{array}$ & $\begin{array}{l}-0.04 \\
(0.05)\end{array}$ \\
\hline $\begin{array}{l}\text { Survival/Selfexpression, } \\
\text { relative to US }\end{array}$ & & & & & & & & & $\begin{array}{c}0.36^{* * *} \\
(0.06)\end{array}$ & $\begin{array}{c}0.36^{* * *} \\
(0.06)\end{array}$ & $\begin{array}{c}0.36^{* * *} \\
(0.06)\end{array}$ & & $\begin{array}{c}0.12 \\
(0.21)\end{array}$ & $\begin{array}{c}0.13 \\
(0.21)\end{array}$ \\
\hline Country FE & Yes & Yes & Yes & Yes & Yes & Yes & Yes & Yes & Yes & Yes & Yes & Yes & Yes & Yes \\
\hline Geo Controls & Yes & Yes & Yes & Yes & Yes & Yes & Yes & Yes & Yes & Yes & Yes & Yes & Yes & Yes \\
\hline Historical Controls & Yes & Yes & Yes & Yes & Yes & Yes & Yes & Yes & Yes & Yes & Yes & Yes & Yes & Yes \\
\hline Adjusted- $R^{2}$ & 0.37 & 0.48 & 0.40 & 0.47 & 0.49 & 0.50 & 0.47 & 0.38 & 0.47 & 0.47 & 0.49 & 0.49 & 0.49 & 0.50 \\
\hline Observations & 4095 & 4095 & 4095 & 4095 & 4095 & 4095 & 4095 & 4095 & 4095 & 4095 & 4095 & 4095 & 4095 & 4095 \\
\hline
\end{tabular}


Table C.6: WVS Cultural Dimensions and Income (All Controls)

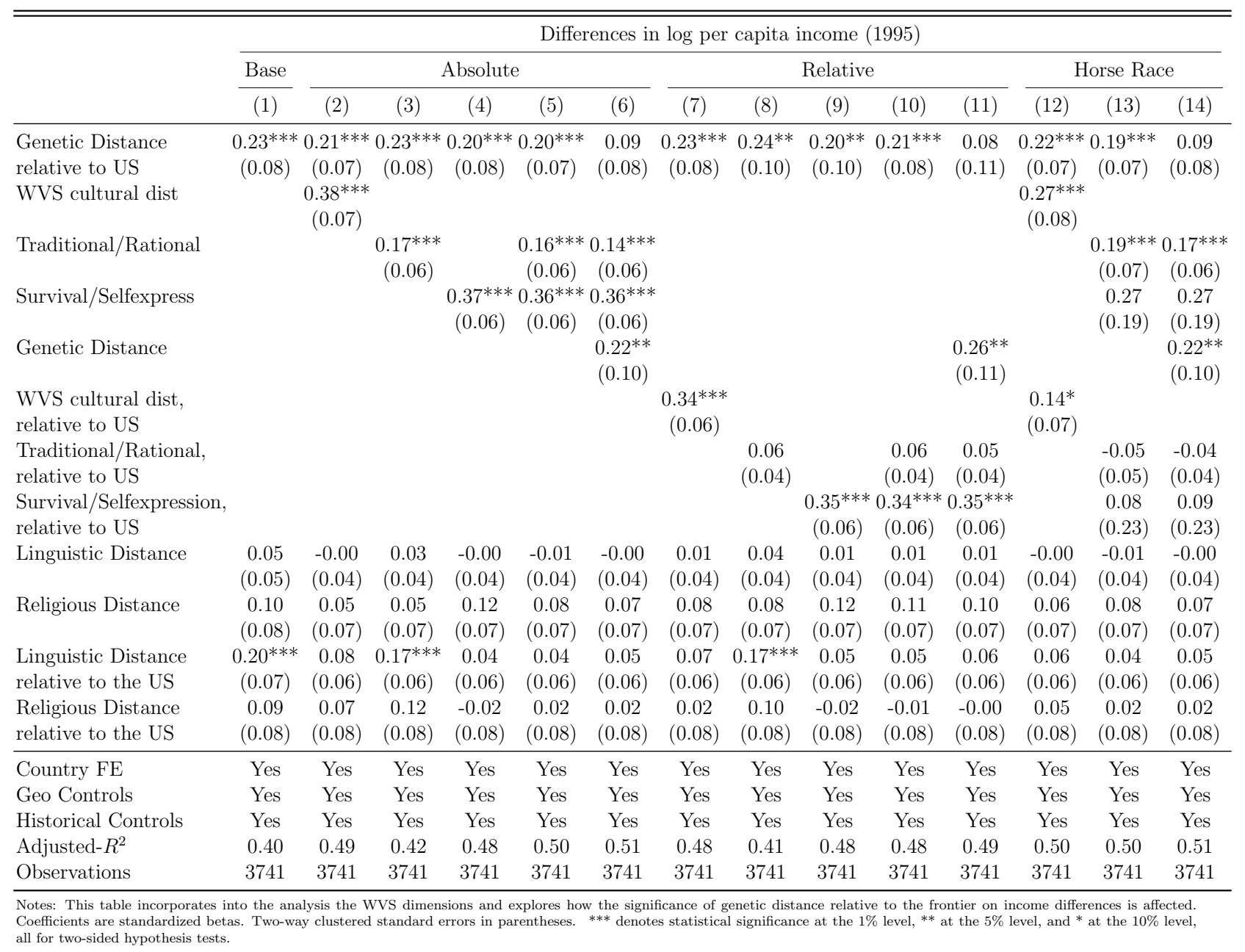

